\title{
Using a Brain-Based Learning Program for Optimizing EFL In-Service Teachers' Professional Delivery of Instruction
}

Dalia Ali Maher Abbass Mohammed

A Lecturer of TEFL Methodology

at the Dept. of Curriculum \& Instruction

Faculty of Education, Minia University 


\title{
Using a Brain-Based Learning Program for Optimizing EFL In-Service Teachers' Professional Delivery of Instruction
}

\author{
D. A. M. Abbass \\ Dalia Ali Maher Abbass \\ Dept. of Curriculum \& Instruction (English Section) \\ Faculty of Education, Minia University \\ E-mail:daliaali@yahoo.com \\ daliaabbass2@gmail.com
}

\begin{abstract}
:
The present study was conducted to investigate the impact of using a brain-based learning program for optimizing EFL in-service teachers' professional delivery of instruction. The study used the quasiexperimental research design (pre-post control-experimental design). Thirty-six EFL in-service teachers enrolled in the professional diplomaMethodology Branch- at the Faculty of Education were randomly assigned to two intact groups: experimental( $n=18)$ and control $(n=18)$. The participants in the experimental group only were instructed using a brainbased learning program whereas their counterparts did not receive such training as they received regular instruction. Instruments of the study included a questionnaire of teachers' professional instruction, a checklist of BB lesson design strategies, a test of brain-based learning strategies and a rubric of positivist e-portfolio. The findings revealed that the participants in the experimental group significantly surpassed their counterparts in the control group in the post-performance on the checklist of brain-based lesson design strategies, a test of brain-based learning strategies and a rubric of positivist e-portfolio.
\end{abstract}

Keywords: Brain-based learning, Delivery of instruction, knowledgebased level of teaching strategies, lesson-design strategies and positivist e-portfolio

العدد الثامن والثلاثون


استخدام برنامج قائم على التعلم المستند الي الدماغ لتحسين مهنيه نقل

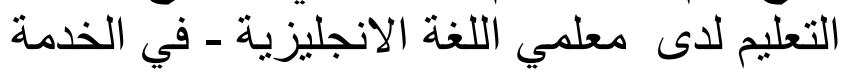

إعداد

داليا على ماهر عباس محمد إعد الهراد

قسم المناهج وطرق التدريس( فرع اللغة الإنجليزية)

كليه التربية- جامعة المنيا

E-mail:daliaali@yahoo.com

daliaabbass2@gmail.com

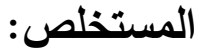

تم اجراء الدراسة الحالية للتعرف على اثر استخدام برنامج قائم علي التعلم المستتد الي الدماغ فى تحسين مهنيه نقل التعليم لدى معلمي اللغة الانجليزية - فى الخدمة-. ولقد تم استخدام

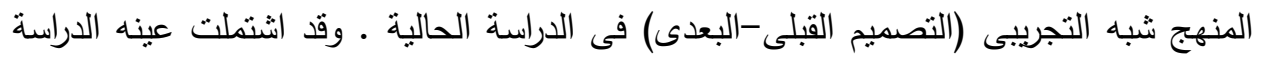

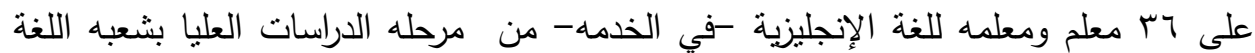
الإنجليزية بكليه التربية-جامعه المنيا ـ وقد تم تقسيمهم بشكل عشوائى الى مجموعتين متساويتين

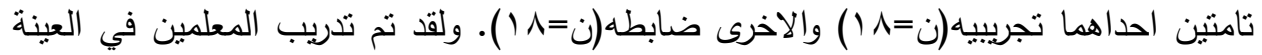
التجريبية باستخدام برنامج قائم على التعلم المستتد الي الدماغ من تصميم الباحثة بينما استخدمت الطريقة المعتادة فى التدريس لمعلمي العينة الضابطة. وقد اشتملت ادوات الدراسة على مقياس مهنيه التعليم لدي معلمى اللغة الإنجليزية، بطاقه فحص لتصميم خطه الدرس قائمه

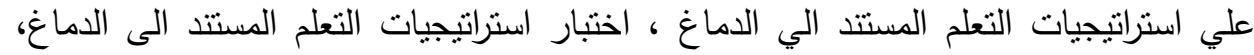

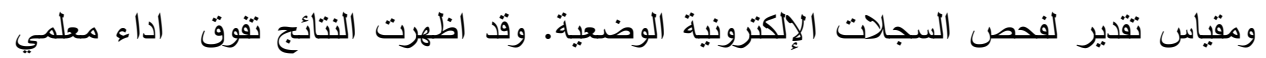

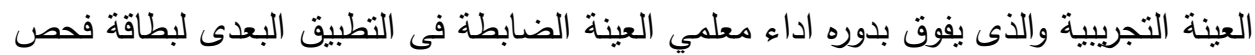

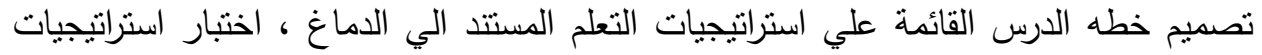
التعلم المستتد الى الدماغ، ومقياس التقدير لفحص السجلات الإلكترونية الوضعية. هذا وقد تم عرض مناقثه و تفسير النتائج والتوصيات والمقترحات لأبحاث مستقبليه.

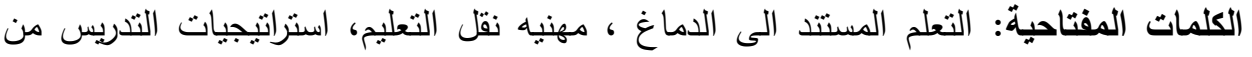
حيث المستوى المعرفي ، استراتيجيات تصميم خطه الدرس ، السجلات الإلكترونية الوضعية. 


\section{Using a Brain-Based Learning Program for Optimizing EFL In-Service Teachers' Professional Delivery of Instruction Dalia Ali Maher Abbass}

\section{Introduction}

English language teaching is vital for successful competition in international transportation, business, tourism, technology, diplomacy, and research. Colleges of education are challenged to prepare future teachers using best practices to help their learners become more efficient thinkers and take smart social, emotional and academic decisions. Consequently, the teacher's role is to facilitate and encourage this process of learning. Every day teachers keep themselves busy considering lesson plans and teaching strategies with the hope that what they are about to present in their classes will be understood, remembered and applied by their students. Realizing this hope depends largely on the knowledge these teachers use in designing those plans and, perhaps more important, on the instructional techniques they select during the lessons. To meet the challenge, educators must understand how the brain functions, collects, processes and interprets information.

There is a wealth of instructional strategies available to choose from which guide instruction, but busy teachers do not have the time and energy to study and research these strategies and methodologies to make informed choices. Moreover, it's the teacher's role to nurture all the needs of all the students with different learning abilities and styles in relation to those students' background knowledge as well as the materials being presented. Because all learning involves the brain, so there is a need to understand how the brain naturally works to align educational practices in the classroom with the way the brain works.

Though there is a wide array of learning theories: behaviorist, cognitive and affective, Haghighi (2013) argues that without a thorough knowledge of learning, all language teaching theories would most likely be doomed to failure. Being aware of the way learning takes place should enhance the level of learners' leaning and achievement, so educational psychologists have focused their research on measurable student behaviors. Behaviorism, as Huang (2006) argues, defines learning as a fundamental part of total human behavior and leads teachers to think that education is only a method to improve behavior with ignoring higher brain functions like emotion and memory. However, this is contrary to the full development of the mind (Caine \& Caine, 1991; Sosa, 2001; Wills, 2007 and Jenson; 2009). As for the constructivist approach, Gulpinar (2005) points out that it led to the prominence of three important concepts: individual differences, contextuality and complexity.

العدد الثامن والثلاثون




\section{Using a Brain-Based Learning Program for Optimizing EFL In-Service Teachers' Professional Delivery of Instruction Dalia Ali Maher Abbass}

Consequently, an important part of educational studies has focused on understanding the learner with his/her differences, complexity and wholeness within a specific sociocultural Context.

Fortunately, this gap from the Industrial Era model of schooling to the Information Era model, according to Wills (2007), was filled by interdisciplinary fields such as neuroscience, neuro-psychology, neurolinguistics, cognitive psychology and education. In the past 20 years, neuroscientists have been employing new technologies to explore the human brain. They have mainly addressed the brain functionally and structurally; memory, emotion, attention, patterning, growth of new dendrites and neural connections with ongoing challenges which resulted in important changes in educational areas (Caine \& Caine 1990; Huang, 2006; Wills, 2007 and Haghigh, 2013). Neuroscience studies have provided a new framework for rethinking about learning and teaching. Thus, educators, according to Wills (2007), Lombardi (2008) and Haghigh (2013), need to build an adequate structure on the basis of the principles of these sciences to step forward towards the information age.

\section{The brain hemispheres}

The human brain is divided into two halves called hemispheres that have a role in determining the way we process information, think, learn and behave. The left hemisphere deals with information in a sequential, analytical manner whereas, the right hemisphere processes information in a more holistic intuitive manner (Caine \& Caine, 1991; Kagan, 2001; Wills, 2007 and Lombardi, 2008). Consequently, as Wills (2007) argues, the left- brain learners respond more to auditory input and verbal messages with a logical manner of thinking, whereas, the rightbrain learners are visual, creative and holistic thinkers who learn best by processing graphs or pictures. In addition, Wills(2007) points out that there are those who would be considered middle-brained. Middle-brain people are more balanced than either left or right brain people and are able to see problems and solve them from different perspectives. Moukaddem and Hernandez (2011) point out that researchers believe that incorporating left and right brain teaching strategies and learning activities can enrich students' learning, enhance their strengths and improve their less developed side.

العدد الثامن والثلاثون




\section{Brain-based learning principles}

Caine and Caine (1990) offered a simple and neurologically sound principles to enable educators and design professionals, when applied to teaching, to reconsider traditional teaching frames and to transform traditional disciplinary thinking in much more interdisciplinary ways. There are at least twelve principles of brain-compatible learning that have emerged from brain research and are clarified by Wilson (2014) as follows:

1- uniqueness - every single brain is totally unique, 2- the impact of threat or high stress can alter and impair learning and even kill brain cells, 3- emotions are critical to learning - they drive our attention, health, learning and memory, 4- information is stored and retrieved through multiple memory and neural pathways, 5- all learning is mind-body movement, foods, attentional cycles and chemicals all have powerful modulating effects on learning, 6- the brain is a complex and adaptive system - effective change involves the entire complex system, 7- patterns and programs drive our understanding - as intelligence is the ability to elicit and to construct useful patterns, 8- the brain is meaning-driven meaning is more important to the brain than information, 9- learning is often rich and non-conscious - we process both parts and wholes simultaneously and are affected a great deal by peripheral influences, 10the brain develops better in concert with other brains - intelligence is more valued in our living social context, 11- the brain develops with various stages of readiness, and 12- enrichment - the brain can grow new connections at any age. Cognitive skills develop better with music and motor skills.

When considering optimal learning environments, Wilson (2014) adds that, design must be approached in a holistic, systemic way, comprising not only the physical setting, but also the social, organizational, pedagogical and emotional environments that are integral to the experience of place.

\section{Brain-based learning}

A brain-based methodology does not necessarily provide a specific systematic approach. However, it does persuade educators to take into account the nature of the brain to facilitate accelerated learning. It collects information from many disciplines, such as chemistry, neurology,

العدد الثامن والثلاثون




\section{Using a Brain-Based Learning Program for Optimizing EFL In-Service Teachers' Professional Delivery of Instruction Dalia Ali Maher Abbass}

psychology, sociology, genetics and biology and focuses on translating neuroimaging data into strategies used in the classroom (Wills, 2007 and Jenson 2009). Such strategies, according to Kagan (2001), Haung (2006) and Lombardi (2008) can aid in addressing various learning styles, multiple intelligences and dealing with students struggling to sustain attention throughout instruction, thereby providing a more differentiated level of instruction.

Learning changes the brain because it can rewire itself with each new behavior, experience, and stimulation (Burkett, 2014). The essential point of brain-based learning is meaningful learning which can be maintained through mapping. Mapping, as Gozuyesil and Dikici (2014) point out, means that new knowledge is linked to previous knowledge and the new knowledge is put into the current system. They add that the phrases of brain-based learning, which make learning meaningful and permanent, are relaxed alertness, orchestrated immersion, and active processing.

Valipour and Araghi (2014) clarified these phrases and considered their educational applications. They assured that a challenging learning environment with minimal threats as well as chances for the students to review how and what they have learnt through reflection and metacognitive activities should be provided to support the optimal emotional and social climate for learning. Moreover, they emphasized that teachers are challenged to select from the wide range of methods and techniques available what can enable them to address the variations and multi-functions of the human brain.

\section{Brain-based instruction}

Brain-based education approaches learning processes differently than traditional teaching methods. For example, Hauang (2006) and Siercks (2012) point out that cognitive learning is a mental process that caters for seeing, memorizing, organizing, processing and solving specific tasks. However, they add, brain-based teaching and learning takes a holistic approach as it considers teaching from a developmental, sociocultural, physiological and psychological way. The brain learns best, as Huang (2006) indicates, when it processes cognitive, affective, and psychomotor information simultaneously. Jensen (2012) concludes that three things are necessary for student success: providing an outlet for

العدد الثامن والثلاثون




\section{Using a Brain-Based Learning Program for Optimizing EFL In-Service Teachers' Professional Delivery of Instruction Dalia Ali Maher Abbass}

emotional expression; reconnecting learners with one another; and helping learners reconnect with the content.

Likewise, Siercks (2012) points out that brain-based instruction emphasizes that the brain does not follow a step-by-step logical path like computer programs but can go a thousand different paths simultaneously. Addressing the brain as a parallel processor, Haung (2006), Wills (2007) and Siercks (2012) emphasize the fact that introducing and reviewing the classroom material by a variety of exposures (touching, seeing, hearing, doing) as well as through several subjects (cross-curricular topics) lead directly to creating more pathways of access in the brain. If the students receive a specific piece of knowledge visually followed by or simultaneous to hearing the same knowledge, they add, this duplication will result in greater chances in the future for long-term memory recall.

Additionally, teaching information should be done in patterns. Patterning, according to Barbiere (2003), is the process whereby the brain perceives and generates patterns by relating new with previously learned material or chunking material into pattern systems it has used before. Education, according to Wills (2007) and Jenson (2012), is about increasing the patterns students can use, recognize and communicate as isolated bits of information are easily forgotten and inaccessible to memory. Being memory enhancers rather than information dispensers, Wills (2007) assures that teachers can help students identify patterns and create networks to process the new working memories (formation of new neural connections) into the brain long-term storage areas.

Hence, educators are challenged to construct and establish an enriched environment that helps the student see the integration between what is taught and what they know. So, as Barbiere (2003), Wills (2007) and Jenson (2012) assure, students can sprout new dendrites, which form new connections and become strong through review. They add that through repeated practice, the neurons fire, become more efficient and be set down as permanent neuronal circuits. Since learning, as Wills (2007) assures, promotes more learning, so repetition of actions through an engaging environment facilitates forming connections between the new memories to the old ones for better information retrieval.

العدد الثامن والثلاثون




\section{The compatible-learning strategies with brain-based learning}

Lombardi (2008) and Bonnema (2009) state the different learning strategies that are related to popular language approaches and are compatible with brain-based learning as follows:

1- Krashan's Language Model (1979) suggests that language is acquired naturally, message is important than form, attitude is more important than aptitude with the importance of the unconscious.

2- Terrell's Natural Approach (Krashen and Terrell 1983) indicates that learning is social and that the instructor has to create a nonthreatening, stimulating environment for best results.

3- Asher's Total Physical Response (1969) indicates that secondlanguage acquisition mirrors first-language acquisition in its commands and physical responses and that motion activates emotion which in turn activates memory.

4- Lozanov's Suggestopedia approach (1978) states that the brain learns consciously and unconsciously, through nonverbal communication, voice, and physical environment, and that learning engages the whole physiology.

5- Gardner's multiple intelligences (1983) suggests it is not how smart we are but how we are smart and that multiple pathways to learning and understanding should be provided in education.

6- MacLean's triune brain theory (1990) states we have three brains, each representing a separate function controlling our emotions, thoughts, and behaviors.

7- Marzano, Pickering, and Pollock (2001) identified categories of research-based instructional strategies that can form a working framework for instructional delivery strongly supported by current brain-based research as follows: (a) identifying similarities and differences for initial processing of information, (b) summarizing and note-taking support the natural plasticity and pruning functions of the brain, (c) giving homework and practice support the memory enhancing strategy of rehearsal, (d) cooperative learning increases intensity in learning new information, (e) using nonlinguistic representations to support coding of various stimuli to increase neural activity, (f) setting objectives and providing feedback to develop learners' metacognitive abilities and their general awareness of both what and how they are learning, and (g)using cues, questions, and

العدد الثامن والثلاثون


advance organizers to support the tendency of the brain to organize knowledge for long-term storage and recall.

\section{Brain-based research and promoting teaching/learning}

Cognitive scientists, exercise physiologists, physical educators, educational psychologists and applied researchers have linked physical activity with cognition. As for the neuroscience, Jensen (2012) emphasizes the correlation between exercise and the production of new cells which is also correlated to improved learning, memory and mood and weight regulation. Accordingly, as Jensen asserts, that the part of the brain that processes movement is the same part of the brain that processes learning, consequently, it is the teacher's role to increase and improve learning processes through involving even the abilities related to dancing, clapping, manipulating and all other natural ones.

Additionally, Wills (2007) and Jenson (2012) point out that there is a consensus that learning involves:(a) a rich environment with meaningful challenges, (b) conscious and unconscious processes, (c) a need for students to reflect on how and what they learn for developing their own meaning, and (d) the learner's social environment, emotion, and social interaction. They add that through applying BBL to classrooms, teachers can help ensure students' various-level needs, such as physiological needs; i.e. the need for water, rest and feeling safe by keeping them free from threats through the feelings of community within the classroom. Celebrations and recognitions can occur regularly so students could maintain a high level of self-esteem. Nurturing learners' different needs, educators can begin to help students meet the highest level on the hierarchy, self-actualization.

\section{Brain-based lesson planning strategies}

In brain-based learning, as Jenson points out (2009), a one-size-fits-all approach does not work. Learning different things requires different approaches for different people, depending on variables such as prior learning, personal experience, special learning styles, the type of skill being taught and reflection. Since every brain is unique, so brain-based lesson planning does not follow a template. Thus, Barbiere (2003) and Jenson (2009) assure that a toolbox rather than a template is the basis for

العدد الثامن والثلاثون


brain-based lesson planning. Through this toolbox, they add, leaners' brains would be enabled to absorb, process and store experiences and information meaningfully.

Jenson (2009) organizes some strategies in a sequence that makes sense to the brain. He emphasizes that specific activities should be planned on the basis of the demographics of the targeted learners to satisfy the goals of each learning stage as follows:

1- Pre-exposure. That provides the learner with an overview of the new learning through using mind-maps, colorful peripherals, good brain nutrition, etc.

2- Preparation. It is similar to the anticipatory set through which the learner 's curiosity is created through a surprise, a bit of novelty or real-life experience.

3- Initiation and acquisition. Here the learner is provided with an overload of ideas, details and meanings to be followed by determination to discover meaning by oneself. This immersion can be done through case studies, hands-on learning or a group project.

4- Elaboration. It is the processing stage which requires learners to make intellectual sense of the learning through exploring the topic online, engaging in group discussions, debates or even doing the teaching as class presenters.

5- Incubation and memory encoding. Here is the down time and review time through stretching and relaxation exercises, music listening periods or unguided reflection.

6- Verification and confidence check. Here teachers and learners need to confirm learning through oral presentations, reflective writings, theatrical performance and quizzes.

7- Celebration and integration. It is the time to engage learners' emotions through playing music, facilitating celebration parties and incorporating the new learning in future classes.

\section{Brain-based learning, reflection and e-portfolio}

The nature and forms of knowledge growth in teacher education begins with the recognition that the ability to reflect on and in action is what characterizes the teaching profession. Reflection, according to Barrett (2007) means being intentionally thoughtful about defining and explaining an experienceas well as determining future implications and

العدد الثامن والثلاثون




\section{Using a Brain-Based Learning Program for Optimizing EFL In-Service Teachers' Professional Delivery of Instruction Dalia Ali Maher Abbass}

actions. It is the addition of reflection, as Rossi, Magnoler and Giannandrea (2008) assert, on the ongoing learning process and the competences acquired that will improve the planning of learning path. Likewise, Jenson (2009) clarifies that the teacher is a master of procedure, content and rationale, and capable of reflection leading to better selfknowledge and metacognitive awareness.

An electronic portfolio uses technologies to enable students or teachers to collect and organize portfolio artifacts in many media types (audio, video, graphics, text). Barrett (2007) identified three fundamental components of learning portfolios: reflection, documentation and collaboration. Additionally, Parkes, Dredger, and Hicks (2013) point out that through using e-portfolios, participants would be provided with the opportunity and virtual space to develop reflections that set their past, present, and future and consider how their ongoing pedagogical decisions and activities influence and shape their own learners' growth.

Through using e-portfolios, as Rossi, Magnoler and Giannandrea (2008) clarify, reflective practice can take many forms; reflection in/ on action, where theories and experience-based practices interact, critical awareness and comparison with previous knowledge before entering a new context; transfer of competences and analysis of the meaning of personal skills and identification of improvement areas and of possible development actions. Zull (2007), Ashikin, Ruhizan and Rohani (2015) assert that as reflection is considered the heart and soul of a portfolio, it is essential for brain-based learning to support reflection towards improving the learning process.

\section{Context of the problem}

Effective teaching is the natural counterpart of effective learning. Teachers get tired of attending training that covers the same material year after year and addresses content, what to teach, rather than methodology, how to teach. Though university schools of education are challenged to prepare future teachers using best practices, most of these schools do not offer courses in neurology or biology, but rather, in educational psychology, which usually provide indirect information about how children learn (Jensen, 2009). It is then the role of higher education to prepare teachers for the paradigm shift they will experience as more and more schools embrace the principles of brain-based learning.

العدد الثامن والثلاثون




\section{Using a Brain-Based Learning Program for Optimizing EFL In-Service Teachers' Professional Delivery of Instruction Dalia Ali Maher Abbass}

To be more specific, the researcher designed and submitted a questionnaire of professional instruction to EFL in-service teachers enrolled at the professional diploma in the Faculty of education, Minia University. The questionnaire aims at informing the researcher about the strategies that EFL in-service teachers usually employ while designing or presenting their lessons in relation to BBL strategies. Concerning lesson designs, their responses showed that most of them either followed the supervisors' or the teachers' manual fixed templates. Planning for motivating, engaging and stimulating classroom atmosphere were the least of their concern. Concerning, the applied strategies of their instruction, they assured that they depended mostly on training workshops or the experts to be informed about the best of these strategies. Ideas like the use of different modalities, music or memory tasks were not common in their teaching. They used to make few use of movement, humor, graphics, hands-on activities, with very limited opportunities for either giving constructive feedback or doing self- reflection.

For instruction to be effective, it must reflect the research-based best practices. The research has already shown that brain-based learning has effective learning outcomes (Haung, 2006; Denton, 2010 and Burkett, 2014). Unlike conventional teaching/learning, the goal of brain-based teaching strategies is to meet the needs of the individual student, enable learners to personalize and to connect with the information through as many senses as possible (visualizing, mimicking, communicating verbally or in writing, etc.). Students would, then, turn to become active and selfmotivated learners, go beyond rote memorization, reach the higher cognitive process of using the information through better improved knowledge application skills. However, there is a gap in the literature regarding English language teachers' awareness, in different grade levels, about brain-based learning strategies and their classroom implementation. Thus, it is important to train teachers to implement brain-based learning strategies and to determine which strategies to use in their classrooms.

\section{Review of related literature}

\section{Theoretical background}

This study of BBL has roots in foreign language theories. It is related to constructivism which states that people gain knowledge and understanding from their own ideas and their experiences with the social and physical world (Burkett, 2014). More specifically, the study

العدد الثامن والثلاثون




\section{Using a Brain-Based Learning Program for Optimizing EFL In-Service Teachers' Professional Delivery of Instruction Dalia Ali Maher Abbass}

corresponds to Piaget's cognitive constructivism that asserts the role of genetic factors, experiences and the environment in controlling the development and formation of knowledge. It is through incorporating BBL strategies that address memory, environment, senses, emotions, learning styles, attention and reflection that students will be able to understand and construct what they have learned (Wills, 2009; Jenson, 2012 and Burkett, 2014).

Moreover, the study addresses social constructivism. Vygotsky's zone of proximal development (ZPD), clarifying the distance between actual developmental level and the level of potential development, is emphasized. In the realm of education, Sikes (2009) points out that ZPD suggests that knowledge is formed within the learner and is brought to the surface by a skilled teacher. This challenges teachers to facilitate learners' natural learning capacities through reflection on their prior knowledge and development of increasingly strong abilities to integrate new information. Aligned with constructivism is brain-based learning. Caine, Caine and McClintic (2002) and Wills (2009) termed this alignment as brain/mind constructivism. This alignment brings with it an innovative model of teaching and learning that emphasizes the construction rather than the transmission of knowledge.

\section{Related studies}

Reviewing the related literature assured that brain-based learning has been reached from a variety of positions. Measuring the general effectiveness of BBL, Gozuyesil and Dikici (2014) conclude that BBL has significant effects on learners regardless of the education level, subject matter and sampling size. More specifically, Haung (2006), Haghighi (2013) and Yagcioglu (2014) have related BBL to students' successful academic achievement and retention, Denton (2010) and Valipour and Araghi (2014) affirm its impact on subsequent instruction to struggling readers and Degen (2012) assures its utility to teaching entrepreneurship students the practice of innovation.

In relation to the positive effects of the implementation of the BBL strategies, Van Roekel (2002) and Burkett (2014) assure the impact of emotion, memory within an enriched BBL environment on learning and Sikes (2009) encourages social change in the classroom through employing brain-based teaching techniques. Concerning the common blocks teachers face through attempting BB teaching strategies, Radin

العدد الثامن والثلاثون




\section{Using a Brain-Based Learning Program for Optimizing EFL In-Service Teachers' Professional Delivery of Instruction Dalia Ali Maher Abbass}

(2005) points out that time, diligence and poorly communicated or dull presentations hinder teachers to understand and apply BBL. Additionally, Bonnema (2009) assures the importance of providing teachers with key elements of the functional characteristics, rather than the biological or structural features, of brain-based learning.

Concerning teachers' perception of BBL, Wagner-Heaston (2006), Denton (2010) and Siercks (2012) emphasize the teachers' interest in the use of movement and/or music, learners' prior knowledge and differentiating instruction to be integrated either in lesson planning or classroom teaching for effective learning outcomes. On the other side, most teachers refer to the difficulties of planning, time, and materials of BBL that are to be included in lessons. Examining some teachers' lessons plans to determine evidence of the implementation of BBL, Barbiere (2003) and Burkett (2014) shed light on the role of past experiences and its relation to new knowledge. Additionally, the effect of emotion, physical movement, music and interest in relation to how new knowledge is transferred, and the organization of data were apparent features through the $\mathrm{BB}$ lesson designs.

Rossi, Magnoler and Giannandrea (2008), Parkes, Dredger, and Hicks (2013) and Harring and Luo (2016) examine the integration of eportfolio for promoting reflection in BBL classes. They assure that eportfolio enables participants to gain deeper levels of critical thinking and reflection skills due to the choice of reflecting with a variety of multimodal methods and allows teachers explore their thought processes when planning and implementing BBL lessons.

\section{Statement of the problem}

Learning about how the brain learns is one of the first steps in becoming an articulate professional educator (Wills, 2009). To effectively meet the challenges of the 21 st century, understanding the best ways to learn has become as important as learning subject matter. Successful brain-based teaching would enable teachers to address the different learning styles in their classrooms while creating environments conducive to all students. Additionally, students would have more pathways (multiple sensory stimulus) to carry new information into their memory storage region and to retrieve the stored knowledge when it is needed. Thus, this study attempted to optimize EFL in-service teachers' professional delivery of instruction through the successful application of

العدد الثامن والثلاثون


the strategies of lesson design, teaching strategies as well as reflection on teaching practices within the pedagogical paradigm of brain-based learning.

\section{Questions of the study}

The present study attempted to answer the following questions:

1- What is the effect of using a brain-based learning program for optimizing EFL in-service teachers' lesson design strategies?

2- What is the effect of using a brain-based learning program for optimizing EFL in-service teachers' knowledge-based level of teaching strategies?

3- What is the effect of using a brain-based learning program for optimizing EFL in-service teachers' reflection using e-portfolio?

\section{Purposes of the study}

The current study attempted to identify:

1- the effect of using a brain-based learning program on optimizing EFL in-service teachers' lesson design strategies.

2- the effect of using a brain-based learning program on optimizing EFL in-service teachers' knowledge-based level of teaching strategies.

3- the effect of using a brain-based learning program on optimizing EFL in-service teachers' reflection using e-portfolio.

\section{Hypotheses of the study}

The present study attempted to test the following hypotheses:

1- there would be a statistically significant difference between mean values obtained by the participants of the experimental and the control groups on the post- performance of the checklist of brain-based lesson design strategies (favoring the experimental group).

2- there would be a statistically significant difference between mean scores obtained by the participants of the experimental and the control

العدد الثامن والثلاثون


groups on the post- performance of the test of brain-based teaching strategies (favoring the experimental group).

3- there would be a statistically significant difference between mean values obtained by the participants of the experimental and the control groups on the post- performance of the rubric of e-portfolio (favoring the experimental group).

\section{Significance of the study}

The implementation of BBL within the realm of higher education in relation to instruction delivery through the present study is hopefully expected to:

- provide students with an enriched environment, with a prevailing mode of instruction, that organizes their lessons as well as their days, uses brain-friendly techniques that energize their minds, encourages social justice in the classroom and fosters optimal learning and longterm retention.

- enable teachers to adjust the design and delivery of educational curricula, as well as the strategies of instruction for increased learning outcomes. Thus, teachers would be provided with justified evidence regarding which techniques and strategies stimulate, and which impede, communication between the parts of the brain where information is processed and stored. Moreover, their positions would be improved by reaching more students through an unthreatening motivating environment.

- enable curriculum designers to close the theory -practice gap of braincompatible teaching and learning by using the evidence-based strategies in actual practice with examining their impact.

- enable supervisors and teachers to have a common language that can be used during reflective conferencing and apply this model to their supervisory style.

- enable university teachers to use the knowledge of gaps gained from this study as feedback for preparation programs and professional development of today's educators.

\section{Delimitations of the study}

العدد الثامن والثلاثون


The present study was delimited to the following elements:

1- The participants are EFL in-service teachers enrolled at the professional diploma, Methodology Branch, Faculty of Education, Minia University, in the second semester of the academic year 2016/2017.

2- The knowledge -based aspect of the brain-based learning strategies is the one addressed and assessed in the present study due to the common ignorance of that aspect in dealing with any teaching strategy.

3- Jenson's (2009) lesson design strategies are the one adopted in the present study.

4- The positivist model of e-portfolio is the one adopted and used in this study.

5- The web-based design of e-portfolio is the one used in this study due to the nature of the adopted ongoing feedback.

\section{Definitions of terms}

\section{Brain-based learning}

- Haung (2006:9) defines it as the incorporation of authentic learning situations that increase the brain's ability to make connections and to retain new information.

- Jenson (2012:5) defines it as the active engagement of practical strategies derived from brain-related sciences.

- Operationally, BBL is used in this study to refer to that type of meaningful leaning that reflects current knowledge of the way the brain processes and utilizes knowledge.

\section{Delivery of instruction}

- Burgstahler (2012) defines delivery of instruction as following a specific approach of teaching to maximize the learning of all students.

- Operationally, it is defined in this study as a systematic way of conveying teaching and learning activities through ready-to-use tactics to promote classroom English language learning.

\section{Brain-based lesson design strategies}

العدد الثامن والثلاثون


- Bonnema (2009: 4) defines brain-based lesson plan as a record of the brain-based practices used in the classroom.

- Operationally, it is defined in this study as a group of brain-based strategies that are organized in a specific sequence in the EFL teacher's written document for classroom application.

\section{Positivist e-portfolio}

- Leon and Pearl Paulson, 1994 (cited in Barrett, 2007:440) define the purpose of the positivist-portfolio as to assess learning outcomes and those outcomes that are, generally, defined externally.

- Parkes, Dredger, and Hicks (2013: 99) define an e-portfolio as a pedagogical space where teaching and learning are as transparent as possible.

- Operationally, the positivist model of e-portfolio is defined in this study as a meaningful documentation tool that EFL in-service teachers use to report on work done, reflect on what and how much learning has occurred and make plans for improving competence.

\section{Method}

\section{Design of the Study}

The present study utilized the quasi-experimental research design. The pre-post control group design (Hatch and Farhady, 1982) was used in designing and conducting the study. An experimental group and a control group were exposed to pre and post means of getting data. The experimental group only was instructed and trained using a brain-based learning program while the control group did not receive such training.

\section{Participants of the Study}

The main sample of the study consisted of thirty-six (36) English majors enrolled in the Methodology branch of the professional diploma at the Faculty of Education, Minia University in the academic year 2016/2017. They were randomly divided into two equal intact groups; experimental and control. Homogeneity was established between participants in both groups at the entry level before the intervention.

r.19 - 19 - 19 -


Age. The two groups of the study were matched on age as the age level of all the participants ranged from 22: 33 years old with nearly the same number in each group. Table (1) shows no significant difference between the students in both groups as the (t) value (0.499) is not significant at 0.05 level.

Table (1)

Means, Standard Deviation and t-value of participants' age

\begin{tabular}{ccccccc}
\hline Group & Subjects & Means & SD & t-value & df & $\begin{array}{c}\text { Sig. (2- } \\
\text { tailed) }\end{array}$ \\
\hline $\begin{array}{c}\text { Experimental } \\
\text { Control }\end{array}$ & 18 & 23.417 & 2.8914 & 0.499 & 34 & 0.621 \\
\hline
\end{tabular}

Note. ${ }^{*}$. Not significant at 0.05 level

Linguistic background. All the participants studied English for 12 years (from primary (1) till the end of the secondary stage at public schools in Minia Governorate) in addition to another 4 to 6 years at their university level till they reached the professional diploma.

Professional experience. All the participants are involved, some way or another, in teaching English. Some of them are teachers at schools, some are language instructors in private centers, some were doing their public service as teachers at schools and the rest were private language tutors. Moreover, all the participants teach students who come from almost the same backgrounds, whether educational, cultural, or working, thus, facing some typical challenges and issues.

\section{Variables of the Study}

The independent variable. The use of a brain-based learning program.

The dependent variables. They include level of performance of lesson design strategies, level of knowledge of brain-based teaching strategies and level of reflection (as represented in their e-portfolios).

\section{Instruments of the study} A questionnaire of teachers' professional instruction.

العدد الثامن والثلاثون


Purpose of the questionnaire. Identifying the knowledge level of lesson planning techniques and teaching strategies that are highly needed for EFL in-service teachers especially in the domain of BBL.

Construction of the questionnaire. a- Reviewing the literature related to the domain of the lesson planning and teaching strategies of BBL. b-Stating the objectives of the questionnaire. c- Designing a preliminary questionnaire. It consists of two variables with nineteen closed-ended questions with pre-defined options in addition to one openended question. d- Evaluating the preliminary form of the questionnaire by a jury of 5 TEFL experts.

Validity of the questionnaire. A jury of 5 TEFL experts approved the face validity of the questionnaire, its suitability and appropriacy for the study sample.

Administration of the questionnaire. The questionnaire was administered to EFL in-service teachers to determine their knowledge level of the lesson design techniques and the teaching strategies.

Results. Analyzing the data obtained revealed that most participants agreed on planning their lesson following either their supervisors' fixed template or the teachers' manual. More specifically, the majority of the participants affirmed the few opportunities they included in their lesson plans for learners' prior knowledge, stimulating activities or real-life experiences. As for the teaching strategies, most of the participants affirmed their major dependence on the teacher's manual for selecting their teaching strategies and that they mostly knew about new strategies from training workshops than any other resources. They affirmed the dominance of their talk with the minimal, or even no wait time given for their learners during their class periods.

Moreover, the inclusion of memory tasks, different learning styles, the five senses, music, physical movement or stimulating class atmosphere is something that they rarely considered in their teaching. Though they assured that they made frequent use of graphics, tables, charts, humor, hands-on activities, constructive feedback, they did not develop their skills for reflection generally and on their teaching practice specifically. All the participants reported their immediate need for 
updated knowledge in the domain of their professional instruction and, particularly, in relation to the most innovative and influential teaching strategies with the development of their reflection skills.

Table (2) presents the percentage of the students' choice of the items of the questionnaire.

Table (2)

\begin{tabular}{|c|c|c|c|c|}
\hline \multirow{2}{*}{$\begin{array}{c}\text { The } \\
\text { Variable } \\
\text { Lesson } \\
\text { planning } \\
\text { techniques }\end{array}$} & $\begin{array}{l}\text { Corresponding } \\
\text { number of } \\
\text { statements }\end{array}$ & \multicolumn{2}{|c|}{ Variable/ Response distribution } & $\begin{array}{c}\text { Total } \\
\text { number } \\
(\mathrm{N})\end{array}$ \\
\hline & 1 & $\begin{array}{l}\text { Follow a fixed- } \\
\text { template (the } \\
\text { supervisor's) }\end{array}$ & $60 \%$ & 20 \\
\hline & & $\begin{array}{c}\text { Follow the teacher's } \\
\text { manual }\end{array}$ & $40 \%$ & \\
\hline & 2 & Often & $30 \%$ & \\
\hline & & Few & $70 \%$ & \\
\hline & 3 & Often & $50 \%$ & \\
\hline & & Few & $50 \%$ & \\
\hline & 4 & Often & $40 \%$ & \\
\hline & & Few & $60 \%$ & \\
\hline & 5 & Often & $50 \%$ & \\
\hline & & Few & $50 \%$ & \\
\hline \multirow[t]{13}{*}{$\begin{array}{l}\text { Teaching } \\
\text { strategies }\end{array}$} & 6 & $\begin{array}{l}\text { As suggested by the } \\
\text { teacher's manual }\end{array}$ & $60 \%$ & \\
\hline & & $\begin{array}{l}\text { The mostly } \\
\text { common ones }\end{array}$ & $40 \%$ & \\
\hline & 7 & From experts & $30 \%$ & \\
\hline & & $\begin{array}{l}\text { From training } \\
\text { workshops }\end{array}$ & $70 \%$ & \\
\hline & 8 & 1 minute & $50 \%$ & \\
\hline & & no time & $50 \%$ & \\
\hline & 9 & Most of the time & $60 \%$ & \\
\hline & & Nearly half the time & $40 \%$ & \\
\hline & 10 & Do not know & $100 \%$ & \\
\hline & 11 & Often & $20 \%$ & \\
\hline & & Few & $80 \%$ & \\
\hline & 12 & Often & $50 \%$ & \\
\hline & & Few & $50 \%$ & \\
\hline
\end{tabular}


Using a Brain-Based Learning Program for Optimizing EFL In-Service Teachers' Professional Delivery of Instruction Dalia Ali Maher Abbass

\begin{tabular}{|c|c|c|c|c|}
\hline $\begin{array}{c}\text { The } \\
\text { Variable }\end{array}$ & $\begin{array}{l}\text { Corresponding } \\
\text { number of } \\
\text { statements }\end{array}$ & Variable/ Re & tribution & $\begin{array}{c}\text { Total } \\
\text { number } \\
(\mathbf{N})\end{array}$ \\
\hline & 13 & Rare & $100 \%$ & \\
\hline & \multirow{2}{*}{14} & Few & $20 \%$ & \\
\hline & & Rare & $80 \%$ & \\
\hline & \multirow[t]{2}{*}{15} & Often & $40 \%$ & \\
\hline & & Few & $60 \%$ & \\
\hline & \multirow[t]{2}{*}{16} & Few & $10 \%$ & \\
\hline & & Rare & $90 \%$ & \\
\hline & \multirow[t]{2}{*}{17} & Often & $40 \%$ & \\
\hline & & Few & $60 \%$ & \\
\hline & \multirow[t]{2}{*}{18} & Often & $40 \%$ & \\
\hline & & Few & $60 \%$ & \\
\hline & \multirow[t]{2}{*}{19} & Often & $30 \%$ & \\
\hline & & Few & $70 \%$ & \\
\hline & 20 & \multicolumn{2}{|c|}{$\begin{array}{l}\text { What type of knowledge do you } \\
\text { specifically need in your } \\
\text { professional career? }\end{array}$} & \\
\hline
\end{tabular}

\section{A checklist of BBL- lesson design strategies}

Purpose of the checklist. A checklist of BBL-lesson design strategies was designed by the researcher for EFL in-service teachers to identify the different BBL strategies they employ while designing the different stages of their lesson plans, ensure equality of the participants in the experimental and control groups through piloting and measure the degree of improvement of the participants in both groups on their design of BBL strategies through the different stages of their lesson plans after the course is over.

Construction of the checklist. It is constructed on the basis of Likert three-point Likert-type scale. The BBL lesson design strategies are represented in the scale through a group of seven stages, each followed by a group of statements for measuring the participants' BBL strategies they usually apply in their lesson design with the total number of 33 statements. Each statement has three response categories rating as follows: weakly represented, occasionally represented and well represented. Responses are given scores (weights) according to the

العدد الثامن والثلاثون


checklist response categories as follows: weakly represented (1), occasionally represented (2) and well represented (3). Maximum score on the checklist is 99 . This is shown in table (3).

Table (3)

The Stages of The BBL Lesson Design Strategies Checklist

\begin{tabular}{|ccc|}
\hline No. & Checklist stages & No. of items \\
\hline 1 & Exposure & 9 \\
2 & Preparation & 4 \\
3 & Initiation and acquisition & 3 \\
4 & Elaboration & 5 \\
5 & Incubation and memory encoding & 5 \\
6 & verification and confidence check & 4 \\
7 & Celebration & 3 \\
Total number & 33 & \\
of items & & \\
Total score & 99 & \\
\hline
\end{tabular}

Instructions of the checklist. They are written in English. They are easy to understand. They include information about the purpose of the checklist, its stages, the distribution of the scores on the points of the checklist and the way of recording the answer.

Piloting the checklist. Piloting the checklist was done with a group of twenty (20) male and female English majors enrolled in other branches of professional diploma at the Faculty of Education, Minia University in the academic year 2016/2017.Those participants were excluded later on from the intervention. Time taken by each rater, for checking each participant's lesson plan was recorded, divided by the whole number of the participants. Then the average of the time spent by each of the two raters, during using the checklist, was calculated and was found to be 20 minutes. Thus, the allotted time for using the checklist was 20 minutes.

\section{Validity of the checklist.}

1- The face validity of the checklist. It was determined by submitting it to a jury of 5 TEFL experts to judge its validity according to the following criteria: linguistic stating of statements,

العدد الثامن والثلاثون


relatedness of the statements to the stages of BBL lesson design strategies and suitability of the statements to the participants. The suggestions and recommendations of the jury members were taken into consideration and the checklist was revised to reach its final form.

2- Pearson correlation. it was used to determine the internal consistency of the checklist. The lesson plans of the same piloting sample (20 EFL in-service teachers enrolled in the professional diploma) were checked using the checklist. The internal consistency of each stage was calculated. The internal consistency of the individual statements of the stages of the checklist was calculated as shown in table (4). The correlation between the seven stages of the checklist and the total checklist was determined as shown in table (5). The values of the correlation coefficient, ranged from (0.451: 0.960), are considered acceptable.

Table (4)

The Internal Consistency of the BBL Lesson Design Strategies Checklist

\begin{tabular}{|c|c|c|c|c|c|}
\hline Item no. & $\begin{array}{c}\text { Internal } \\
\text { consistency }\end{array}$ & $\begin{array}{c}\text { Item } \\
\text { no. }\end{array}$ & $\begin{array}{c}\text { Internal } \\
\text { consistency }\end{array}$ & $\begin{array}{c}\text { Item } \\
\text { no. }\end{array}$ & $\begin{array}{c}\text { Internal } \\
\text { consistency }\end{array}$ \\
\hline A1 & $.552 *$ & B3 & $.619 * *$ & E2 & $.875^{* *}$ \\
\hline A2 & $.603 * *$ & B4 & $.726 * *$ & E3 & $.797 * *$ \\
\hline A3 & $.451 *$ & $\mathrm{C} 1$ & $.760 * *$ & E4 & $.960 * *$ \\
\hline A4 & $.587 * *$ & $\mathrm{C} 2$ & $.836 * *$ & E5 & $.694 * *$ \\
\hline A5 & $.525^{*}$ & C3 & $.794 * *$ & $\mathrm{~F} 1$ & $.737 * *$ \\
\hline A6 & $.691 * *$ & D1 & $.570 * *$ & F2 & $.830 * *$ \\
\hline A7 & $.689 * *$ & D2 & $.690 * *$ & F3 & $.732 * *$ \\
\hline A8 & $.447 *$ & D3 & $.786^{* *}$ & F4 & $.765^{* *}$ \\
\hline A9 & $.612^{* * *}$ & D4 & $.898 * *$ & G1 & $.893 * *$ \\
\hline B1 & $.747 * *$ & D5 & $.798 * *$ & G2 & $.949 * *$ \\
\hline B2 & $.912 * *$ & E1 & $.875 * *$ & G3 & $.834 * *$ \\
\hline
\end{tabular}

Note. ${ }^{* *}$. Correlation is significant at the 0.01 level (2-tailed).

Note. *. Correlation is significant at the 0.05 level (2-

tailed).

Table (5)

The Correlation Between Each Stage and The Total Checklist Stages Internal consistency 
Using a Brain-Based Learning Program for Optimizing EFL In-Service Teachers' Professional Delivery of Instruction Dalia Ali Maher Abbass

\begin{tabular}{|cc|}
\hline Exposure & $.664^{* *}$ \\
Preparation & $.530^{*}$ \\
Initiation and acquisition & $.538^{*}$ \\
Elaboration & $.679^{*}$ \\
Incubation and memory encoding & $.488^{*}$ \\
verification and confidence check & $.629^{*}$ \\
Celebration & $.450^{*}$ \\
\hline
\end{tabular}

Note. ${ }^{* *}$. Correlation is significant at the 0.01 level (2-tailed).

Note. *. Correlation is significant at the 0.05 level (2tailed).

Reliability of the checklist. Establishing the reliability of the checklist was done during piloting. The lesson plans of the same piloting sample (20 EFL in-service teachers enrolled in the professional diploma) were checked using the checklist. The reliability coefficient of the checklist was determined using:

a- Alpha Cronbach (a) coefficient. It equals (0.857) and is considered acceptable as shown in table (6).

Table (6)

The Cronbach Alpha's Reliability Coefficient of the Checklist

\begin{tabular}{|cccccc|}
\hline Stages & Means & Variance & $\begin{array}{c}\text { Standard } \\
\text { Deviation }\end{array}$ & $\begin{array}{c}\text { No. of } \\
\text { items }\end{array}$ & Alpha \\
\hline $\begin{array}{c}\text { Pre-Exposure } \\
\text { Preparation }\end{array}$ & 13.70 & 6.326 & 2.515 & 9 & 0.740 \\
$\begin{array}{c}\text { Initiation and } \\
\text { acquisition }\end{array}$ & 4.90 & 1.253 & 1.119 & 3 & 0.712 \\
$\begin{array}{c}\text { Elaboration } \\
\text { Incubation }\end{array}$ & 8.10 & 3.884 & 1.971 & 5 & 0.805 \\
$\begin{array}{c}\text { and memory } \\
\text { encoding }\end{array}$ & 5.80 & 2.484 & 1.576 & 5 & 0.898 \\
$\begin{array}{c}\text { verification } \\
\text { and }\end{array}$ & 5.35 & 2.239 & 1.496 & 4 & 0.755 \\
$\begin{array}{c}\text { confidence } \\
\text { check }\end{array}$ & & & & & \\
$\begin{array}{c}\text { Celebration } \\
\text { Total of }\end{array}$ & 3.70 & 1.589 & 1.261 & 3 & 0.869 \\
dimensions & 48.65 & 44.555 & 6.675 & 33 & 0.857 \\
\hline
\end{tabular}

Note. *. Alpha is significant at the 0.05 level (2-tailed). 
b- Test- retest method. It occurred with nearly two weeks intervals between the first and the second ratings. It was administered on the same randomly chosen piloting sample (20 EFL in-service teachers enrolled in the professional diploma) for calculating reliability coefficient of the checklist. The total reliability coefficient of the checklist is (0.988) which is considered acceptable as shown in table (7).

Table (7)

Test-Retest Reliability Coefficient of the Checklist

\begin{tabular}{|c|c|c|c|c|c|c|c|}
\hline $\begin{array}{l}\text { Dimension } \\
\mathrm{s}\end{array}$ & $\begin{array}{c}\text { Mean } \\
\mathrm{s}\end{array}$ & SD & $\begin{array}{c}\text { Mean } \\
\mathrm{s}\end{array}$ & SD & $\begin{array}{c}\mathrm{t}- \\
\text { valu } \\
\mathrm{e}\end{array}$ & $\begin{array}{l}\text { Sig. } \\
(2- \\
\text { tailed } \\
\quad) \\
\end{array}$ & $\begin{array}{c}\text { Correlatio } \\
\mathrm{n}\end{array}$ \\
\hline $\begin{array}{c}\text { Pre- } \\
\text { exposure }\end{array}$ & 13.60 & $\begin{array}{c}2.39 \\
3\end{array}$ & 13.70 & $\begin{array}{c}2.51 \\
5\end{array}$ & $\begin{array}{c}- \\
0.809\end{array}$ & 0.428 & $.976^{* *}$ \\
\hline Preparation & 7.15 & $\begin{array}{c}1.56 \\
5\end{array}$ & 7.10 & $\begin{array}{c}1.48 \\
3\end{array}$ & 0.370 & 0.716 & $.923 * *$ \\
\hline $\begin{array}{l}\text { Initiation } \\
\quad \text { and } \\
\text { acquisition }\end{array}$ & 4.85 & $\begin{array}{c}1.18 \\
2\end{array}$ & 4.90 & $\begin{array}{c}1.11 \\
9\end{array}$ & $\begin{array}{c}- \\
0.567\end{array}$ & 0.577 & $.943 * *$ \\
\hline Elaboration & 8.20 & $\begin{array}{c}2.11 \\
8\end{array}$ & 8.10 & $\begin{array}{c}1.97 \\
1\end{array}$ & 1.000 & 0.330 & $.979 * *$ \\
\hline $\begin{array}{l}\text { Incubation } \\
\text { and } \\
\text { memory } \\
\text { encoding }\end{array}$ & 5.85 & $\begin{array}{c}1.46 \\
1\end{array}$ & 5.80 & $\begin{array}{c}1.57 \\
6\end{array}$ & 0.567 & 0.577 & $.969 * *$ \\
\hline $\begin{array}{l}\text { verification } \\
\text { and } \\
\text { confidence } \\
\text { check }\end{array}$ & 5.35 & $\begin{array}{c}1.46 \\
1\end{array}$ & 5.35 & $\begin{array}{c}1.49 \\
6\end{array}$ & 0.000 & 1.000 & $.952 * *$ \\
\hline Celebration & 3.75 & $\begin{array}{c}1.25 \\
1\end{array}$ & 3.70 & $\begin{array}{c}1.26 \\
1\end{array}$ & 1.000 & 0.330 & $.984 * *$ \\
\hline $\begin{array}{c}\text { Total of } \\
\text { dimensions }\end{array}$ & 48.75 & $\begin{array}{c}6.51 \\
2 \\
\end{array}$ & 48.65 & $\begin{array}{c}6.67 \\
5 \\
\end{array}$ & 0.438 & 0.666 & $.988 * *$ \\
\hline
\end{tabular}

Note. **. Correlation is significant at the 0.01 level (2-tailed). (t) value is not significant at the 0.01 level (2-tailed)

c- The Peasron correlation formula. It was also used to determine the inter-rater reliability of the checklist. Two raters 
with approximately the same academic level checked the lesson plans of the same piloting sample (20 EFL in-service teachers enrolled in the professional diploma) using the checklist. The mean scores received by the participants were calculated. The inter-rater reliability is (0.726) as shown in table (8).

Table (8)

The Inter-rater Reliability of the Checklist

\begin{tabular}{|c|c|c|c|c|c|}
\hline No & Total R1 & Total R2 & Total & Average X & $\mathrm{X}^{2}$ \\
\hline 1 & 56 & 53 & 109 & 54.5 & 2970.25 \\
\hline 2 & 45 & 49 & 94 & 47 & 2209 \\
\hline 3 & 48 & 53 & 101 & 50.5 & 2550.25 \\
\hline 4 & 51 & 49 & 100 & 50 & 2500 \\
\hline 5 & 44 & 47 & 91 & 45.5 & 2070.25 \\
\hline 6 & 45 & 42 & 87 & 43.5 & 1892.25 \\
\hline 7 & 51 & 45 & 96 & 48 & 2304 \\
\hline 8 & 53 & 48 & 101 & 50.5 & 2550.25 \\
\hline 9 & 49 & 44 & 93 & 46.5 & 2162.25 \\
\hline 10 & 43 & 48 & 91 & 45.5 & 2070.25 \\
\hline 11 & 51 & 49 & 100 & 50 & 2500 \\
\hline 12 & 41 & 45 & 86 & 43 & 1849 \\
\hline 13 & 55 & 52 & 107 & 53.5 & 2862.25 \\
\hline 14 & 55 & 59 & 114 & 57 & 3249 \\
\hline 15 & 50 & 46 & 96 & 48 & 2304 \\
\hline 16 & 41 & 47 & 88 & 44 & 1936 \\
\hline 17 & 42 & 48 & 90 & 45 & 2025 \\
\hline
\end{tabular}


Using a Brain-Based Learning Program for Optimizing EFL In-Service Teachers' Professional Delivery of Instruction Dalia Ali Maher Abbass

\begin{tabular}{|cccccc|}
\hline \hline 18 & 63 & 56 & 119 & 59.5 & 3540.25 \\
19 & 55 & 54 & 109 & 54.5 & 2970.25 \\
20 & 35 & 41 & 76 & 38 & 1444 \\
Inter-rater & & & $.726^{* *}$ & & \\
\hline
\end{tabular}

Note. **. Correlation is significant at the 0.01 level (2-tailed).

Cohen et al. (2007:530) point out that the reliability coefficients are considered reliable if they range from 0.50 to 0.90 . Thus, the reliability coefficients of the checklist are considered within the acceptable range.

\section{A Test of Brain-Based Learning/ Teaching Strategies}

Purpose of the test. A test of brain-based learning/teaching strategies was designed by the researcher for EFL in-service teachers enrolled in the professional diploma to assess the knowledge-based level of their teaching strategies, ensure equality of the participants in the experimental and control groups through piloting and measure the degree of improvement of the participants in both groups on their knowledgebased level of the brain-based learning/teaching strategies after finishing the course.

Construction of the test. It consists of 100 items for the whole test. It is constructed according to a table of specification on the basis of the knowledge-based level of the BBL topics of the suggested program. Items are of the multiple-choice type. One point is given for each test item. The maximum score of this test is 100 .

Instructions of the test. They are written in English. They are brief and easy to understand. They include information about the purpose of the test, the way of recording the answers and the time allowed to complete the test.

Piloting the test. Piloting the test was done with a group of twenty (20) male and female English majors enrolled in other branches of professional diploma at the Faculty of Education, Minia University in the academic year 2016/2017. Those participants were excluded later on from

العدد الثامن والثلاثون


the intervention. Time taken by each student was recorded, divided by the whole number of students who took the test which was found to be 130 minutes. Thus, the testing time was 130 minutes.

\section{Validity of the test.}

1- The face validity of the test. It was determined by submitting it to a jury of 5 TEFL experts to judge its validity according to the following criteria: linguistic stating of items, how far the items measure the objectives of the program and suitability of items for the participants. The suggestions and recommendations of the jury members were taken into consideration and the test was revised to reach its final form.

2- Pearson correlation formula. It was used to determine the internal consistency of the test. $20 \mathrm{EFL}$ in-service teachers enrolled in the professional diploma were selected randomly to take the test. The internal consistency of each item was calculated as shown in table (9). The values of the correlation coefficient, ranged from (0.451: 0.712 ), are considered acceptable.

Table (9)

The Internal Consistency of the Test of Brain-based Learning/Teaching Strategies

\begin{tabular}{|cccccccc|}
\hline $\begin{array}{c}\text { Ite } \\
\mathrm{m} \\
\text { no. }\end{array}$ & $\begin{array}{c}\text { Internal } \\
\text { consistenc }\end{array}$ & $\begin{array}{c}\text { Ite } \\
\mathrm{m}\end{array}$ & $\begin{array}{c}\text { Internal } \\
\text { consistenc }\end{array}$ & $\begin{array}{c}\text { Ite } \\
\mathrm{m}\end{array}$ & $\begin{array}{c}\text { Internal } \\
\text { consistenc } \\
\text { no. }\end{array}$ & $\begin{array}{c}\text { Ite } \\
\mathrm{y}\end{array}$ & $\begin{array}{c}\text { Internal } \\
\text { consistenc } \\
\text { no. }\end{array}$ \\
\hline 1 & $.543^{*}$ & 26 & $.537^{*}$ & 51 & $.485^{*}$ & 76 & $.573^{* *}$ \\
2 & $.538^{*}$ & 27 & $.535^{*}$ & 52 & $.539^{*}$ & 77 & $.459^{*}$ \\
3 & $.538^{*}$ & 28 & $.514^{*}$ & 53 & $.456^{*}$ & 78 & $.449^{*}$ \\
4 & $.483^{*}$ & 29 & $.488^{*}$ & 54 & $.480^{*}$ & 79 & $.547^{*}$ \\
5 & $.472^{*}$ & 30 & $.510^{*}$ & 55 & $.512^{*}$ & 80 & $.459^{*}$ \\
6 & $.466^{*}$ & 31 & $.468^{*}$ & 56 & $.460^{*}$ & 81 & $.520^{*}$ \\
7 & $.530^{*}$ & 32 & $.486^{*}$ & 57 & $.508^{*}$ & 82 & $.508^{*}$ \\
8 & $.505^{*}$ & 33 & $.500^{*}$ & 58 & $.463^{*}$ & 83 & $.630^{*}$ \\
9 & $.522^{*}$ & 34 & $.538^{*}$ & 59 & $.508^{*}$ & 84 & $.501^{*}$ \\
10 & $.553^{*}$ & 35 & $.451^{*}$ & 60 & $.455^{*}$ & 85 & $.448^{*}$ \\
11 & $.485^{*}$ & 36 & $.506^{*}$ & 61 & $.496^{*}$ & 86 & $.510^{*}$ \\
12 & $.483^{*}$ & 37 & $.505^{*}$ & 62 & $.496^{*}$ & 87 & $.457^{*}$ \\
13 & $.464^{*}$ & 38 & $.516^{*}$ & 63 & $.519^{*}$ & 88 & $.464^{*}$ \\
14 & $.536^{*}$ & 39 & $.471^{*}$ & 64 & $.522^{*}$ & 89 & $.512^{*}$ \\
15 & $.455^{*}$ & 40 & $.484^{*}$ & 65 & $.483^{*}$ & 90 & $.521^{*}$ \\
16 & $.534^{*}$ & 41 & $.513^{*}$ & 67 & $.512^{*}$ & 91 & $.560^{*}$ \\
17 & $.538^{*}$ & 42 & $.530^{*}$ & 68 & $.496^{*}$ & 92 & $.522^{*}$
\end{tabular}


Using a Brain-Based Learning Program for Optimizing EFL In-Service Teachers' Professional Delivery of Instruction

Dalia Ali Maher Abbass

\begin{tabular}{|llllllll|}
\hline \hline 18 & $.491^{*}$ & 43 & $.482^{*}$ & 69 & $.500^{*}$ & 93 & $.475^{*}$ \\
19 & $.459^{*}$ & 44 & $.466^{*}$ & 70 & $.527^{*}$ & 94 & $.536^{*}$ \\
20 & $.543^{*}$ & 45 & $.496^{*}$ & 71 & $.475^{*}$ & 95 & $.508^{*}$ \\
21 & $.488^{*}$ & 46 & $.508^{*}$ & 71 & $.508^{*}$ & 96 & $.540^{*}$ \\
22 & $.504^{*}$ & 47 & $.712^{*}$ & 72 & $.542^{*}$ & 97 & $.468^{*}$ \\
23 & $.565^{*}$ & 48 & $.549^{*}$ & 73 & $.473^{*}$ & 98 & $.467^{*}$ \\
24 & $.548^{*}$ & 49 & $.449^{*}$ & 74 & $.497^{*}$ & 99 & $.508^{*}$ \\
25 & $.520^{*}$ & 50 & $.538^{*}$ & 75 & $.471^{*}$ & 100 & $.516^{*}$ \\
\hline
\end{tabular}

Reliability of the test. Establishing the reliability of the test was done during piloting. The same piloting sample (20 EFL in-service teachers) were randomly selected to take the test. The reliability coefficient of the test was determined using:

1- The split-half method. Spearman-Brown Coefficient of the test is 0.930. It is considered acceptable as shown in table (10)

Table (10)

The Split-half Reliability coefficient of the test

\begin{tabular}{|cccccc|}
\hline The test & Means & Variance & $\begin{array}{c}\text { Standard } \\
\text { Deviation }\end{array}$ & $\begin{array}{c}\text { No. of } \\
\text { items }\end{array}$ & $\begin{array}{c}\text { Spearman- } \\
\text { Brown } \\
\text { Coefficient }\end{array}$ \\
\hline Part 1 & Part 1 & 22.15 & 172.450 & 13.132 & 0.930 \\
Part 2 & Part 2 & 24.30 & 171.589 & 13.099 & \\
Both & Both & 46.45 & 643.103 & 25.359 & \\
Parts & Parts & & & & \\
\hline
\end{tabular}

Note. ${ }^{*}$ Correlation is significant at the 0.05 level.

2- Alpha Cronbach (a) coefficient. It is (0.971) and is considered acceptable as shown in table (11).

Table (11)

The Cronbach Alpha's Reliability coefficient of the test

\begin{tabular}{|cccccc|}
\hline The test & Means & Variance & $\begin{array}{c}\text { Standard } \\
\text { Deviation }\end{array}$ & $\begin{array}{c}\text { No. of } \\
\text { items }\end{array}$ & Alpha \\
\hline Statistics & 46.45 & 643.103 & 25.359 & 100 & 0.971 \\
\hline
\end{tabular}

Note. ${ }^{*}$. Alpha is significant at the 0.05 level (2-tailed). 
Cohen et al. (2007:506) point out that the split half coefficient and the alpha coefficient are considered reliable if they range from 0.70 to 0.90 . Thus, both of the reliability coefficients of the test are considered within the acceptable range.

Item analysis. It evaluates the effectiveness of the items and of the test as a whole.

Index of difficulty. Analysis of the responses to individual items was calculated to determine item difficulty for the test. The difficulty of the items is understood as the proportion of the persons who answer a test item correctly. The index of difficulty of this test ranged from0.30 to 0.70 .

Item discrimination. It is the ability of the item to differentiate more knowledgeable students from the less knowledgeable. To calculate knowledge, the top scoring students are separated from the bottom scoring students and then their response patterns would be compared. After calculating the discriminating power of the items, it was found that the items had a positive discriminating power. None of the items had a zero- discriminating power. The power of discrimination of the test ranged from 0.30 to 0.60 .

\section{A Rubric of Positivist E-portfolio}

Purpose of the rubric. A rubric for the positivist e-portfolio was designed by the researcher for EFL in-service teachers to reflect on their professional teaching practices and measure the degree of improvement of the participants in both groups on the depth of their reflection insights after finishing the course.

Construction of the rubric. It is constructed on the basis of a three-point Likert-type scale. The most important dimensions of designing an e-portfolio are classified and represented in the rubric through a group of four dimensions, each followed by a group of statements that are developed for measuring participants' ability for reflection through using and designing a personal positivist e-portfolio with the total number of 11 statements. Each statement has three response categories rating as follows: unsatisfactory, emerging and proficient.

العدد الثامن والثلاثون


Responses are given scores (weights) according to the scale response categories as follows: unsatisfactory (1), emerging (2) and proficient (3). Maximum score on the rubric is 33. This is shown in table (12)

Table (12)

The Dimensions of The Positivist E-portfolio Rubric

\begin{tabular}{|ccc|}
\hline No. & Rubric dimensions & No. of items \\
\hline 1 & Technology & 2 \\
2 & Content & 5 \\
3 & Overall presentation & 2 \\
4 & Personality features & 2 \\
Total number of items & 11 & \\
Total score & 33 & \\
\hline
\end{tabular}

Instructions of the rubric. They are written in English. They are easy to understand. They include information about the purpose of the rubric, its dimensions, the distribution of the scores on the scale points of the rubric and the way of recording the answer.

Piloting the rubric. Piloting the rubric was done with a group of twenty (20) male and female English majors enrolled in other branches of professional diploma at the Faculty of Education, Minia University in the academic year 2016/2017. Those participants were excluded later on from the intervention. Time taken by the researcher for navigating through each participant's e-portfolio was recorded, divided by the whole number of participants whose e-portfolios were checked using the rubric and was found to be 40 minutes. Thus, the time allotted for using the rubric was 40 minutes.

\section{Validity of the rubric.}

1- The face validity of the rubric. It was determined by submitting it to a jury of 5 TEFL experts to judge its validity according to the following criteria: linguistic stating of statements, relatedness of the statements to the dimensions of e-portfolios and suitability of the statements to the participants. The suggestions and recommendations of the jury members were taken into consideration and the rubric was revised to reach its final form. 
2- Pearson correlation. It was used to determine the internal consistency of the rubric. The rubric was used by the researcher to navigate through the e-portfolios of the participants in the treatment group (18 EFL in-service teachers enrolled in the Methodology branch of the professional diploma). The internal consistency of each dimension of the rubric was calculated. The internal consistency of the individual statements of the dimensions of the rubric was calculated as shown in table (13). The correlation between the four dimensions of the rubric and the total rubric was determined as shown in table (14). The values of the correlation coefficient, ranged from (0.737: 0.926), are considered acceptable.

Table (13)

The Internal Consistency of the Positivist E-portfolio Rubric

\begin{tabular}{|cccccc|}
\hline Item no. & $\begin{array}{c}\text { Internal } \\
\text { consistency }\end{array}$ & $\begin{array}{c}\text { Item } \\
\text { no. }\end{array}$ & $\begin{array}{c}\text { Internal } \\
\text { consistency }\end{array}$ & $\begin{array}{c}\text { Item } \\
\text { no. }\end{array}$ & $\begin{array}{c}\text { Internal } \\
\text { consistency }\end{array}$ \\
\hline A1 & $.880^{* *}$ & B3 & $.851^{* *}$ & C2 & $.904^{* *}$ \\
A2 & $.880^{* *}$ & B4 & $.666^{* *}$ & D1 & $.926^{* *}$ \\
B1 & $.811^{* *}$ & B5 & $.898^{* *}$ & D2 & $.878^{* *}$ \\
B2 & $.737^{* *}$ & C1 & $.893^{* *}$ & - & - \\
\hline
\end{tabular}

Note. ${ }^{* *}$. Correlation is significant at the 0.01 level (2-tailed).

Table (14)

The Correlation Between Each Dimension and The Total Rubric

\begin{tabular}{|cc|}
\hline Dimensions & Internal consistency \\
\hline Technology & $.910^{* *}$ \\
Content & $.963^{* *}$ \\
Overall presentation & $.815^{* *}$ \\
Personality features & $.853^{* *}$ \\
\hline
\end{tabular}

Note. ${ }^{* *}$. Correlation is significant at the 0.01 level (2-tailed).

Reliability of the rubric. Establishing the reliability of the rubric was done using the results recorded by the researcher through using the rubric for navigating through the e-portfolios of the participants in the treatment group (18 EFL in-service teachers enrolled in the Methodology branch of the professional diploma). The reliability coefficient of the rubric was determined using: 
1- The split-half method. Guttman Split-Half Coefficient of the scale is 0.879 . It is considered acceptable as shown in table (15).

Table (15)

The Split-half Reliability coefficient of the Positivist E-portfolio Rubric

\begin{tabular}{|cccccc|}
\hline The test & Means & Variance & $\begin{array}{c}\text { Standard } \\
\text { Deviation }\end{array}$ & $\begin{array}{c}\text { No. of } \\
\text { items }\end{array}$ & $\begin{array}{c}\text { Guttman } \\
\text { Split-Half } \\
\text { Coefficient }\end{array}$ \\
\hline Part 1 & 15.28 & 5.742 & 2.396 & $6 \mathrm{a}$ & 0.879 \\
Part 2 & 13.50 & 3.794 & 1.948 & $5 \mathrm{~b}$ & \\
Both Parts & 28.78 & 17.007 & 4.124 & 11 & \\
\hline
\end{tabular}

Note, Correlation is significant at the 0.05 level (2-tailed)

2- Alpha Cronbach ( $\alpha$ ) coefficient. It is (0.929). It is considered acceptable as shown in table (16).

Table (16)

The Cronbach Alpha's Reliability Coefficient of the Positivist E-portfolio Rubric

\begin{tabular}{|cccccc|}
\hline Domains & Means & Variance & $\begin{array}{c}\text { Standard } \\
\text { Deviation }\end{array}$ & $\begin{array}{c}\text { No. of } \\
\text { items }\end{array}$ & Alpha \\
\hline Technology & 5.11 & 0.810 & 0.900 & 2 & 0.710 \\
$\begin{array}{c}\text { Content } \\
\text { Overall }\end{array}$ & 5.39 & 0.722 & 0.850 & 2 & 0.760 \\
$\begin{array}{c}\text { presentation } \\
\text { Personality } \\
\text { features } \\
\begin{array}{c}\text { Total of } \\
\text { dimensions }\end{array}\end{array}$ & 5.50 & 0.618 & 0.786 & 2 & 0.762 \\
\hline
\end{tabular}

Note. *. Alpha is significant at the 0.05 level (2-tailed).

Cohen et al. (2007:506) point out that the split half coefficient and the alpha coefficient are considered reliable if they range from 0.70 to 0.90 . Thus, both of the reliability coefficients of the rubric are considered within the acceptable range.

\section{The material}

a- The material (the training program) consists of four units: one for the introduction (setting-up an e-portfolio in addition to some prerequisite general information), another two units for BB teaching strategies (e.g. whole class indoor recess activities, attention skills, mnemonics, 
coping skills, etc.) and another one for BB lesson design strategies (Jenson's seven stages of lesson design strategies).

b- The construction of the training program has gone through the following steps: reviewing the literature related to the domain of the lesson planning techniques and teaching strategies of BBL, stating the general and the specific objectives of each lesson, preparing the content, submitting the program to some jury members to be judged according to the following criteria; statement of items, academic verification of the content, appropriateness of the method and the techniques used for the content and the participants of the study and applicability of the program.

\section{Instructional design of the study}

1- A questionnaire of EFL teachers' professional instruction was designed and applied by the researcher to be informed about the instructional practices of EFL in-service teachers in relation to lesson design techniques and the applied teaching strategies.

2- Pre-testing the participants of both the experimental and control groups using the test of $\mathrm{BB}$ teaching strategies $(\mathrm{N}=36)$. Additionally, their lesson designs would be checked using the checklist of BB lesson design strategies before the intervention to ensure their homogeneity at the entry level.

\section{3- The experimental treatment.}

a- Participants at the experimental group were trained using the brain-based learning program that integrates lesson design strategies, BB teaching strategies with the practices of reflection through positivist e-portfolios. BB research findings were used to optimize teachers' delivery of instruction as well as reflection through the combination of $\mathrm{BB}$ lesson design tactics and knowledge-based level of teaching strategies supported by the pedagogical space of e-portfolio.

b- A learning community platform (face book account) was created to help the participants interact and collaborate together, share knowledge, exchange questions and answers, initiate inquiries about language use and foster interpersonal communication.

c- The positivist model of e-portfolio would be formed by the participants for the sake of developing reflection of their teaching practices following four umbrella steps:

1- Self - introduction (- Short term and long-term goals (personal, academic and professional)/ - responsibilities 
(personal, academic and professional)/ - personal philosophy (what is good teaching? and the role of teachers)/ and favorite teaching approaches.

2- Tasks: - compulsory (responses to topical questions and tasks relating to an area of study focusing on brain-based research and education)/ - additional (enhancement with their references)

3- lesson planning strategies

4- Reflection (on their teaching practices and beliefs when implementing brain-based learning strategies).

5- Experts' scaffolding (using the received feedback comments (the researcher or other experts of the field) to improve submitted materials assigned for tasks.

c- Insuring the maximum development of the participants' knowledge of BBL was maintained through groupwork, workshops, active learning strategies, minute papers- reflection activities among other varieties of different teaching and learning strategies.

d- An ongoing constructive dialogue between the researcher and the participants supports reflection on learning through their e-portfolios as a medium of interaction to inform the researcher about the participants' skills and knowledge.

e- Publication of e-portfolios would be done on the basis of learners' personal decisions through specifying the persons with whom they would like to share their e-portfolios.

4- The control treatment. Participants in the control group received instruction on the course of Modern Trends in Teaching using the regular way with no brain-based learning intervention.

5- Post testing the participants in both groups $(\mathrm{N}=36)$ using the test of BB teaching strategies. Additionally, their lesson designs would be checked using the checklist of BB lesson design strategies and their eportfolios were also checked using the rubric of e-portfolio.

\section{Instructor}

The researcher taught the experimental group only using the brainbased learning program by herself while she taught the control group using the regular procedures according to the rules of the institution. 


\section{Findings}

\section{Hypothesis 1}

The first hypothesis of the study predicted that there was a statistically significant difference (favoring the experimental group) between mean values obtained by the participants of the experimental and the control groups on the post- performance of the checklist of BB lesson design strategies. Statistical analysis of the obtained data showed that the experimental group achieved a higher degree of improvement than the control group as t-value (35.450) is significant at (0.05) level and beyond. Thus, the first hypothesis is confirmed. Table (17) below shows the data obtained to test this hypothesis.

Table (17)

Means, Standard Deviation, $\mathrm{t}$ value, $\eta 2$ and effect size on the postperformance of both the experimental and control groups of the BB Lesson Design Strategies Checklist.

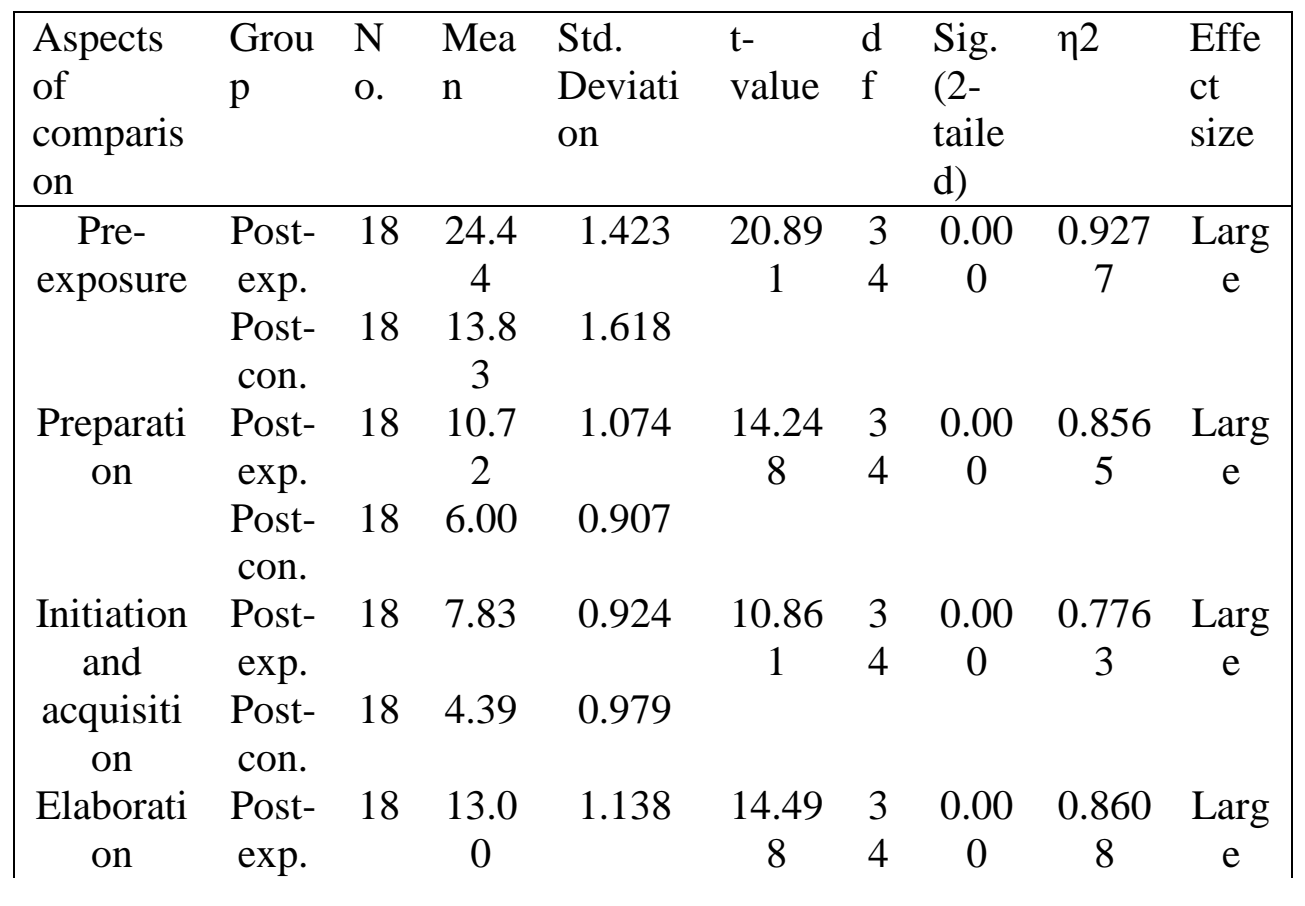




\begin{tabular}{|c|c|c|c|c|c|c|c|c|c|}
\hline & Post- & 18 & 7.61 & 1.092 & & & & & \\
\hline \multirow{6}{*}{$\begin{array}{l}\text { Incubatio } \\
n \text { and } \\
\text { memory } \\
\text { encoding } \\
\text { verificati } \\
\text { on and } \\
\text { confiden } \\
\text { ce check }\end{array}$} & Post- & 18 & 13.2 & 1.320 & \multirow{3}{*}{$\begin{array}{c}18.00 \\
9\end{array}$} & \multirow{3}{*}{$\begin{array}{l}3 \\
4\end{array}$} & \multirow{3}{*}{$\begin{array}{c}0.00 \\
0\end{array}$} & \multirow{3}{*}{$\begin{array}{c}0.905 \\
1\end{array}$} & \multirow{3}{*}{$\begin{array}{c}\text { Larg } \\
\mathrm{e}\end{array}$} \\
\hline & exp. & & 8 & & & & & & \\
\hline & $\begin{array}{l}\text { Post- } \\
\text { con. }\end{array}$ & 18 & 6.44 & 0.922 & & & & & \\
\hline & Post- & 18 & 10.8 & 0.786 & \multirow{3}{*}{$\begin{array}{c}23.09 \\
2\end{array}$} & \multirow{3}{*}{$\begin{array}{l}3 \\
4\end{array}$} & \multirow{3}{*}{$\begin{array}{c}0.00 \\
0\end{array}$} & \multirow{3}{*}{$\begin{array}{c}0.940 \\
1\end{array}$} & \multirow{3}{*}{$\begin{array}{c}\text { Larg } \\
\mathrm{e}\end{array}$} \\
\hline & exp. & & 3 & & & & & & \\
\hline & $\begin{array}{l}\text { Post- } \\
\text { con. }\end{array}$ & 18 & 4.89 & 0.758 & & & & & \\
\hline \multirow{3}{*}{$\begin{array}{c}\text { Celebrati } \\
\text { on }\end{array}$} & Post- & 18 & 8.22 & 0.878 & \multirow{3}{*}{$\begin{array}{c}15.80 \\
0\end{array}$} & & 0.00 & 0.880 & \multirow{3}{*}{$\begin{array}{c}\text { Larg } \\
\mathrm{e}\end{array}$} \\
\hline & exp. & & & & & \multirow{2}{*}{4} & \multirow{2}{*}{0} & \multirow[t]{2}{*}{1} & \\
\hline & $\begin{array}{l}\text { Post- } \\
\text { con. }\end{array}$ & 18 & 3.83 & 0.786 & & & & & \\
\hline \multirow{3}{*}{$\begin{array}{c}\text { Total of } \\
\text { dimensio } \\
\text { ns }\end{array}$} & Post- & 18 & 88.3 & 3.481 & \multirow{3}{*}{$\begin{array}{c}35.45 \\
0\end{array}$} & \multirow{3}{*}{$\begin{array}{l}3 \\
4\end{array}$} & \multirow{3}{*}{$\begin{array}{c}0.00 \\
0\end{array}$} & \multirow{3}{*}{$\begin{array}{c}0.973 \\
7\end{array}$} & \multirow{3}{*}{$\begin{array}{l}\text { Larg } \\
\mathrm{e}\end{array}$} \\
\hline & exp. & & 3 & & & & & & \\
\hline & $\begin{array}{l}\text { Post- } \\
\text { con. }\end{array}$ & 18 & $\begin{array}{c}47.0 \\
0\end{array}$ & 3.515 & & & & & \\
\hline
\end{tabular}

Note. *. significant at the 0.05 level (2-tailed).

To ensure the impact of BB program on improving participants' lesson design of BBL strategies, eta-squared formula statistics $(\eta 2)$ was used. Cohen et al. (2007:522) pointed out that when eta-squared value $=$ 0.01, the effect is considered weak, when it $=0.06$, the effect is considered medium and when it $=0.14$ the effect is large. As shown in table (17) eta-squared value $(\eta 2)$ equals (0.9737) which is considered large. Thus, BBL based- program is considered with high impact on improving EFL in-service teachers' lesson design of brain-based learning strategies.

Additionally, the comparison of the values obtained by the participants of both the experimental and control groups in the pre-post performance on the checklist of BB lesson design strategies revealed that the experimental group outperformed the control group as t-value (40.800) is significant at 0.05 level and beyond. Eta- squared value $(\eta 2)$ equals (0.9899) which is considered large.

The results showed that the control group achieved some improvement in the post-performance on some dimensions of the checklist of $\mathrm{BB}$ lesson design strategies due to the common teaching 
strategies included in the checklist and can be performed professionally by any teacher. However, the improvement of the experimental group was larger as eta-squared value $(\eta 2)$ for the experimental group equals (0.9899) which is considered high and greater than the eta-squared value $(\eta 2)$ for the control group which equals (0.0295). Thus, the brainbased learning program is considered more effective than the regular instruction in improving participants' lesson design of BB teaching strategies. This is shown in table (18).

Table

Means, Standard Deviation, $\mathrm{t}$ value, $\eta 2$ and effect size between mean scores of the experimental and the control group on the Pre-Post of the Brain-based Lesson Planning Strategies Checklist. N=18

\begin{tabular}{|c|c|c|c|c|c|c|c|c|c|}
\hline $\begin{array}{l}\text { Aspects } \\
\text { of } \\
\text { comparis } \\
\text { on }\end{array}$ & $\begin{array}{l}\text { Gro } \\
\text { up }\end{array}$ & $\begin{array}{c}\text { Mea } \\
\mathrm{n}\end{array}$ & $\begin{array}{c}\text { Mea } \\
n \\
\text { diff. }\end{array}$ & $\begin{array}{l}\text { Stan } \\
\text { d. } \\
\text { Dev. }\end{array}$ & $\begin{array}{c}\mathrm{t}- \\
\text { value }\end{array}$ & $\begin{array}{l}d \\
f\end{array}$ & $\begin{array}{l}\text { Sig. } \\
(2- \\
\text { taile } \\
\text { d) }\end{array}$ & $\eta 2$ & $\begin{array}{c}\text { Effect } \\
\text { size }\end{array}$ \\
\hline \multirow{8}{*}{$\begin{array}{c}\text { Pre- } \\
\text { exposure }\end{array}$} & Pre- & 13.8 & - & 1.61 & - & 1 & 0.00 & 0.95 & \multirow[t]{4}{*}{ Large } \\
\hline & exp. & 3 & 10.6 & 8 & 19.7 & 7 & 0 & 83 & \\
\hline & Post & 24.4 & 11 & 1.42 & 56 & & & & \\
\hline & -exp. & 4 & & 3 & & & & & \\
\hline & Pre- & 13.6 & - & 1.50 & - & 1 & 0.10 & 0.14 & \multirow[t]{4}{*}{ Large } \\
\hline & con. & 1 & 0.22 & 1 & 1.71 & 7 & 4 & 81 & \\
\hline & Post & 13.8 & 2 & 1.61 & 9 & & & & \\
\hline & -con. & 3 & & 8 & & & & & \\
\hline \multirow{8}{*}{$\begin{array}{c}\text { Preparati } \\
\text { on }\end{array}$} & Pre- & 6.11 & - & 0.90 & - & 1 & 0.00 & 0.91 & \multirow[t]{4}{*}{ Large } \\
\hline & exp. & & 4.61 & 0 & 13.7 & 7 & 0 & 78 & \\
\hline & Post & 10.7 & 1 & 1.07 & 77 & & & & \\
\hline & -exp. & 2 & & 4 & & & & & \\
\hline & Pre- & 5.94 & - & 0.93 & - & 1 & 0.66 & 0.01 & \multirow[t]{4}{*}{ Small } \\
\hline & con. & & 0.05 & 8 & 0.43 & 7 & 8 & 11 & \\
\hline & Post & 6.00 & 6 & 0.90 & 7 & & & & \\
\hline & -con. & & & 7 & & & & & \\
\hline \multirow{6}{*}{$\begin{array}{l}\text { Initiation } \\
\text { and } \\
\text { acquisiti } \\
\text { on }\end{array}$} & Pre- & 4.39 & - & 0.91 & - & 1 & 0.00 & 0.84 & \multirow[t]{4}{*}{ Large } \\
\hline & exp. & & 3.44 & 6 & 9.71 & 7 & 0 & 75 & \\
\hline & Post & 7.83 & 4 & 0.92 & 8 & & & & \\
\hline & -exp. & & & 4 & & & & & \\
\hline & Pre- & 4.28 & - & 1.01 & - & 1 & 0.33 & 0.05 & \multirow[t]{2}{*}{ Small } \\
\hline & con. & & 0.11 & 8 & 1.00 & 7 & 1 & 56 & \\
\hline
\end{tabular}




\begin{tabular}{|c|c|c|c|c|c|c|c|c|c|}
\hline \multirow{6}{*}{$\begin{array}{c}\text { Elaborati } \\
\text { on }\end{array}$} & $\begin{array}{l}\text { Post } \\
\text {-con. }\end{array}$ & 4.39 & 1 & $\begin{array}{c}0.97 \\
9\end{array}$ & 0 & & & & \multirow{4}{*}{ Large } \\
\hline & Pre- & 7.56 & - & 0.98 & - & 1 & 0.00 & 0.90 & \\
\hline & exp. & & 5.44 & 4 & 12.9 & 7 & 0 & 74 & \\
\hline & Post & 13.0 & 4 & 1.13 & 07 & & & & \\
\hline & -exp. & 0 & & 8 & & & & & \multirow{7}{*}{$\begin{array}{c}\text { Mediu } \\
\text { m }\end{array}$} \\
\hline & Pre- & 7.44 & - & 1.29 & - & 1 & 0.18 & 0.10 & \\
\hline \multirow{11}{*}{$\begin{array}{l}\text { Incubati } \\
\text { on and } \\
\text { memory } \\
\text { encoding }\end{array}$} & con. & & 0.16 & 4 & 1.37 & 7 & 7 & 00 & \\
\hline & Post & 7.61 & 7 & 1.09 & 4 & & & & \\
\hline & -con. & ( & \multicolumn{3}{|c|}{2} & & & \multirow{4}{*}{$\begin{array}{c}0.95 \\
84\end{array}$} & \\
\hline & Pre- & 6.44 & - & 0.98 & - & 1 & 0.00 & & \\
\hline & exp. & & 6.83 & 4 & 19.7 & 7 & 0 & & \\
\hline & Post & 13.2 & 3 & 1.32 & 85 & & & & \multirow{6}{*}{ Large } \\
\hline & -exp. & 8 & & 0 & & & & & \\
\hline & Pre- & 6.28 & - & 0.82 & - & 1 & 0.08 & 0.16 & \\
\hline & con. & & 0.16 & 6 & 1.84 & 7 & 3 & 67 & \\
\hline & Post & 6.44 & 7 & 0.92 & 4 & & & & \\
\hline & -con. & & & 2 & & & & & \\
\hline \multirow{5}{*}{$\begin{array}{l}\text { verificati } \\
\text { on and } \\
\text { confiden } \\
\text { ce check }\end{array}$} & Pre- & 5.28 & - & 0.75 & - & 1 & 0.00 & 0.97 & \multirow[t]{2}{*}{ Large } \\
\hline & exp. & & 5.55 & 2 & 25.5 & 7 & 0 & 47 & \\
\hline & Post & 10.8 & 6 & 0.78 & 70 & & & & \multirow{6}{*}{ Large } \\
\hline & -exp. & 3 & & 6 & & & & & \\
\hline & Pre- & 5.17 & 0.27 & 0.78 & 2.05 & 1 & 0.05 & 0.19 & \\
\hline \multirow{8}{*}{$\begin{array}{c}\text { Celebrati } \\
\text { on }\end{array}$} & con. & \multirow{3}{*}{4.89} & 8 & 6 & 1 & 7 & 6 & 84 & \\
\hline & Post & & & 0.75 & & & & & \\
\hline & -con. & & & 8 & & & & & \\
\hline & Pre- & 3.89 & - & 0.96 & - & 1 & 0.00 & 0.93 & \multirow[t]{4}{*}{ Large } \\
\hline & exp. & & 4.33 & 3 & 16.1 & 7 & 0 & 89 & \\
\hline & Post & 8.22 & 3 & 0.87 & 61 & & & & \\
\hline & -exp. & & & 8 & & & & & \\
\hline & Pre- & 4.00 & 0.16 & 0.76 & 1.14 & 1 & 0.26 & 0.07 & Mediu \\
\hline \multirow{9}{*}{$\begin{array}{c}\text { Total of } \\
\text { dimensio } \\
\text { ns }\end{array}$} & con. & & 7 & 7 & 4 & 7 & 9 & 15 & $\mathrm{~m}$ \\
\hline & Post & 3.83 & & 0.78 & & & & & \multirow{4}{*}{ Large } \\
\hline & -con. & & & 6 & & & & & \\
\hline & Pre- & 47.5 & - & 2.22 & - & 1 & 0.00 & 0.98 & \\
\hline & exp. & 0 & 40.8 & 9 & 40.8 & 7 & 0 & 99 & \\
\hline & Post & 88.3 & 33 & 3.48 & 00 & & & & \multirow{4}{*}{ Small } \\
\hline & -exp. & 3 & & 1 & & & & & \\
\hline & Pre- & 46.7 & - & 3.21 & - & 1 & 0.48 & 0.02 & \\
\hline & con. & 2 & 0.27 & 4 & 0.71 & 7 & 2 & 95 & \\
\hline
\end{tabular}




\begin{tabular}{|c|c|c|c|c|}
\hline $\begin{array}{l}\text { Post } \\
\text {-con. }\end{array}$ & $\begin{array}{c}47.0 \\
0\end{array}$ & 8 & $\begin{array}{c}3.51 \\
5\end{array}$ & 9 \\
\hline
\end{tabular}

Note. *. significant at the 0.05 level (2-tailed).

\section{Hypothesis 2}

The second hypothesis of the study predicted that there was a statistically significant difference (favoring the experimental group) between mean scores obtained by the participants of the experimental and the control groups on the post- performance of the test of BB teaching strategies. Statistical analysis of the obtained data showed that the experimental group achieved a higher degree of improvement than the control group as t-value (14.053) is significant at (0.05) level and beyond. Thus, the second hypothesis is confirmed. Table (19) below shows the data obtained to test this hypothesis.

Table (19)

Means, Standard deviation, mean difference, $t$ value, $\eta 2$ and effect size on the post-performance of both the experimental and control group of the brain-based learning strategies test.

\begin{tabular}{|c|c|c|c|c|c|c|c|c|c|c|}
\hline $\begin{array}{l}\text { Aspects } \\
\text { of } \\
\text { compari } \\
\text { son } \\
\end{array}$ & $\begin{array}{c}\text { Gro } \\
\text { up }\end{array}$ & $\begin{array}{l}\mathrm{N} \\
\mathrm{o} .\end{array}$ & $\begin{array}{l}\mathrm{Me} \\
\text { an }\end{array}$ & $\begin{array}{c}\text { Mea } \\
n \\
\text { diff. }\end{array}$ & $\begin{array}{l}\text { Std. } \\
\text { Deviat } \\
\text { ion }\end{array}$ & $\begin{array}{c}\mathrm{t}- \\
\text { valu } \\
\mathrm{e}\end{array}$ & $\begin{array}{l}d \\
f\end{array}$ & $\begin{array}{l}\text { Sig. } \\
(2- \\
\text { taile } \\
\text { d) }\end{array}$ & $\eta 2$ & $\begin{array}{c}\text { Effe } \\
\text { ct } \\
\text { size }\end{array}$ \\
\hline Total & $\begin{array}{c}\text { Post } \\
- \\
\text { exp. } \\
\text { Post } \\
- \\
\text { con. }\end{array}$ & 18 & $\begin{array}{l}41 . \\
67\end{array}$ & $\begin{array}{c}32.3 \\
33\end{array}$ & 7.063 & $\begin{array}{c}14.0 \\
53\end{array}$ & $\begin{array}{l}3 \\
4\end{array}$ & $\begin{array}{c}0.00 \\
0\end{array}$ & $\begin{array}{c}0.85 \\
31\end{array}$ & $\begin{array}{l}\text { Lar } \\
\text { ge }\end{array}$ \\
\hline
\end{tabular}

Note. *. significant at the 0.05 level (2-tailed).

To ensure the impact of the BB program on improving participants' knowledge-based level of BB learning/teaching strategies, eta-squared formula statistics ( $\eta 2$ ) was used. Cohen et al. (2007:522) point out that when eta-squared value $=0.01$, the effect is considered weak, when it $=$ 0.06 , the effect is considered medium and when it $=0.14$ the effect is large. As shown in table (18) eta-squared value $(\eta 2)$ equals $(0.8531)$ which is considered large. Thus, the $\mathrm{BB}$ learning program is considered with 
high impact on improving EFL in-service teachers' knowledge-based level of teaching strategies.

Additionally, the comparison of the scores obtained by the participants of both the experimental and control groups in the pre-post performance on the test of brain-based learning/teaching strategies revealed that the experimental group outperformed the control group as tvalue (13.266) is significant at (0.05) level and beyond. Eta- squared value $(\eta 2)$ equals $(0.9119)$ which is considered large.

The results showed that the control group achieved some improvement in the post-performance on the test of knowledge-based level of BB learning/teaching strategies due to their involvement in the course of Modern Trends of Teaching. However, the improvement of the experimental group was larger as eta-squared value ( $\eta 2)$ for the experimental group equals $(0.9119)$ which is considered high and greater than the eta-squared value $(\eta 2)$ for the control group which equals (0.0847). Thus, the BB learning program is considered more effective than the regular instruction in improving learners' knowledge-based level of teaching strategies. This is shown in table (20)

Table (20)

Means, Standard Deviation, $\mathrm{t}$ value, $\eta 2$ and effect size between mean scores of the experimental and the control group on the Pre-Post of the brain-based learning strategies test. $\mathrm{N}=18$

\begin{tabular}{cccccccccc}
\hline $\begin{array}{c}\text { Aspects } \\
\text { of } \\
\text { comparis } \\
\text { on }\end{array}$ & $\begin{array}{c}\text { Gro } \\
\text { up }\end{array}$ & $\begin{array}{c}\text { Mea } \\
\mathrm{n}\end{array}$ & $\begin{array}{c}\text { Mea } \\
\mathrm{n} \\
\text { diff. }\end{array}$ & $\begin{array}{c}\text { Stan } \\
\mathrm{d} . \\
\text { Dev. }\end{array}$ & $\begin{array}{c}\text { t- } \\
\text { value }\end{array}$ & $\begin{array}{c}\mathrm{d} \\
\mathrm{f}\end{array}$ & $\begin{array}{c}\text { Sig. } \\
(2- \\
\text { taile } \\
\text { d) }\end{array}$ & $\begin{array}{c}\eta 2 \\
\text { Effect } \\
\text { size }\end{array}$ \\
\hline Total & Pre- & 40.7 & - & 5.41 & - & 1 & 0.00 & 0.91 & Large \\
& exp. & 8 & 33.2 & 8 & 13.2 & 7 & 0 & 19 & \\
& Post & 74.0 & 22 & 7.06 & 66 & & & & \\
& -exp. & 0 & & 3 & & & & & \\
& Pre- & 41.2 & 1.50 & 7.09 & - & 1 & 0.22 & 0.08 & Mediu \\
& con. & 2 & 4 & 2 & 1.25 & 7 & 7 & 47 & m \\
& Post & 41.6 & & 6.73 & 4 & & & & \\
\hline -con. & 7 & & 9 & & & & & \\
\hline
\end{tabular}

Note. *. significant at the 0.05 level (2-tailed). 


\section{Hypothesis 3}

The third hypothesis of the study predicted that there was a statistically significant difference (favoring the experimental group) between mean values obtained by the participants of the experimental and the control groups on the post- performance of the rubric of e-portfolio. Statistical analysis of the obtained data showed that the experimental group achieved a higher degree of improvement in reflection than the control group on the rubric of e-portfolio as t- value (6.061) is significant at (0.05) level and beyond. Thus, the third hypothesis is confirmed. Table (21) below shows the data obtained to test this hypothesis.

Table

Means, Standard Deviation, $\mathrm{t}$ value, $\eta 2$ and effect size on the postperformance of both the experimental and control group of the positivist e-portfolio rubric.

\begin{tabular}{|c|c|c|c|c|c|c|c|c|c|}
\hline $\begin{array}{l}\text { Aspects } \\
\text { of } \\
\text { comparis } \\
\text { on }\end{array}$ & $\begin{array}{l}\text { Gro } \\
\text { up }\end{array}$ & $\begin{array}{l}\mathrm{N} \\
\mathrm{o} .\end{array}$ & $\begin{array}{l}\mathrm{Me} \\
\text { an }\end{array}$ & $\begin{array}{l}\text { Std. } \\
\text { Deviati } \\
\text { on }\end{array}$ & $\begin{array}{c}\mathrm{t}- \\
\text { valu } \\
\mathrm{e}\end{array}$ & df & $\begin{array}{l}\text { Sig. } \\
(2- \\
\text { taile } \\
\text { d) }\end{array}$ & $\eta 2$ & $\begin{array}{l}\text { Effe } \\
\text { ct } \\
\text { size }\end{array}$ \\
\hline $\begin{array}{c}\text { Technol } \\
\text { ogy }\end{array}$ & $\begin{array}{c}\text { Post } \\
- \\
\text { exp. } \\
\text { Post } \\
- \\
\text { con. }\end{array}$ & 18 & 3.89 & 0.900 & $\begin{array}{c}4.83 \\
5\end{array}$ & $\begin{array}{c}29.1 \\
26\end{array}$ & $\begin{array}{c}0.00 \\
0\end{array}$ & $\begin{array}{c}0.40 \\
74\end{array}$ & $\begin{array}{c}\text { Larg } \\
\mathrm{e}\end{array}$ \\
\hline Content & $\begin{array}{c}\text { Post } \\
- \\
\text { exp. } \\
\text { Post } \\
- \\
\text { con. }\end{array}$ & 18 & $\begin{array}{c}12.7 \\
8\end{array}$ & 0.608 & $\begin{array}{c}2.79 \\
8\end{array}$ & $\begin{array}{c}20.0 \\
63\end{array}$ & $\begin{array}{c}0.01 \\
1\end{array}$ & $\begin{array}{c}0.18 \\
72\end{array}$ & $\begin{array}{l}\text { Larg } \\
\mathrm{e}\end{array}$ \\
\hline $\begin{array}{l}\text { Overall } \\
\text { presentat } \\
\text { ion }\end{array}$ & $\begin{array}{c}\text { Post } \\
- \\
\text { exp. } \\
\text { Post } \\
- \\
\text { con. } \\
\text { Post }\end{array}$ & 18 & 5.28 & 0.826 & $\begin{array}{c}2.61 \\
5\end{array}$ & 34 & $\begin{array}{c}0.01 \\
3\end{array}$ & $\begin{array}{c}0.16 \\
74\end{array}$ & $\begin{array}{l}\text { Larg } \\
\mathrm{e}\end{array}$ \\
\hline
\end{tabular}




\begin{tabular}{cccccccccc}
\hline \hline ty & - & & & & 34 & & 0 & 46 & $\mathrm{e}$ \\
features & exp. & & & & & & & & \\
& Post & 18 & 2.56 & 0.705 & & & & & \\
& - & & & & & & & & \\
& con. & & & & & & & & \\
Total of & Post & 18 & 28.6 & 4.102 & 6.06 & 34 & 0.00 & 0.51 & Larg \\
dimensio & - & & 7 & & 1 & & 0 & 93 & $\mathrm{e}$ \\
ns & exp. & & & & & & & & \\
& Post & 18 & 22.4 & 1.464 & & & & & \\
& - & & 4 & & & & & & \\
& con. & & & & & & & & \\
\hline
\end{tabular}

Note. ${ }^{*}$. significant at the 0.05 level (2-tailed).

To ensure the impact of the BB learning program on improving participants' abilities of reflection through using their e-portfolios, etasquared formula statistics ( $\eta 2$ ) was used. Cohen et al. (2007:522) point out that when eta-squared value $=0.01$, the effect is considered weak, when it $=0.06$, the effect is considered medium and when it $=0.14$ the effect is large. As shown in table (21) eta-squared value( $\eta 2)$ equals (0.5193) which is considered large. Thus, the brain-based learning program is considered with high effect in improving EFL in-service teachers' reflection through using their e-portfolios.

\section{Discussion}

\section{The inherent features of the study on the basis of the participants' reflections}

The beginning stages of the experiment were highly influential. Issuing an e-portfolio for each participant for uploading course assignments, extra personal enhancements as well as on-going reflection on personal learning and teaching practices was a challenge. However, through videos and vivid examples, the task became manageable. Likewise, having a digital account for the experimental group on the Face Book was a worthy idea as it was their virtual corner where they exchanged experiences and materials and, most importantly, develop the habit of ongoing reflection. Both digital platforms served as their best companions through the BBL journey.

The introductory phase of the intervention, where human needs, kinds of motivation, different learning styles and multiple intelligences

العدد الثامن والثلاثون


discussed, paved the way smoothly towards BBL. The definition, BBL principles and neurological concepts (e.g. orchestrated immersion, plasticity, etc.) formed a gap in the participants' thinking as revealed in their reflection comments. However, the materials presented, the enhancements they got and shared (e.g. videos, images, brief articles, ...) and the ongoing discussion in class or through their virtual space helped in bridging these gaps. Addressing the different BBL teaching and lesson design strategies through videos, images and case studies was engaging. The participants felt positive and more self-efficient towards receiving and applying the recent evidence-based teaching strategies.

\section{The interpretation of the results with reference to the related literature}

Increasing teachers' knowledge of BB research would impact their subsequent instruction and enable their students to become more successful learners (Haung, 2006; Denton, 2010; Haghighi, 2013; Valipour \& Araghi, 2014 and Yagcioglu, 2014) and better reflective practitioners especially through the use of e-portfolio (Rossi et al., 2008; Parkes et al., 2013; Burkett, 2014 and Harring \&Tian Luo,2016). More specifically, tackling the different BB teaching strategies is found to be influential in reaching all students (Wagner-Heaston, 2006; Denton, 2010 and Siercks, 2012), developing BB lesson design strategies (Barbiere, 2003 and Burkett, 2014) as well as promoting lifelong learning and sustainable development (Sikes, 2009; Degen, 2012 and Siercks, 2012).

\section{The relation of the present study's results to the results of other conducted studies}

Results of studies that coincide with those obtained by the present study. The findings of the present study corresponded with Stern, 2005 (cited in Sikes, 2009), Haung (2006) and Burkett (2014) in emphasizing the impact of BBL in promoting better leaning and teaching outcomes. Moreover, BBL is mutually supported by reflection in bridging gaps between theory and practice (Parkes et al., 2013; Burkett, 2014 and Harring \& Tian Luo, 2016).

Results of studies that show the limitations of BBL. Opponents to BBL emphasize the need for educators to learn from many aspects, the psychological, the biological and the sociological in order not to lose sight of man as a whole (Van Roekel, 2002)and to stick to the tried and true methods of classroom teaching and learning that have been proven

العدد الثامن والثلاثون


successful over time (Radin, 2005; Sikes, 2009 and Colburn, 2009, (cited in Burkett, 2014). They add that BBL focuses upon learning rather than test scores and is usually poorly communicated which can make it unattractive to administrators (Radin, 2009). Likewise, some researchers viewed reflection through e-portfolios as busywork (Harring and Tian Luo, 2016).

\section{Conclusion}

The brain is a marvelous organ that can be tapped into, taught, stimulated and grown. Teachers are highly resourceful and creative as they keep on trying thousands of strategies in the classrooms around the world. The issue is, can we make better-informed decisions about teaching based on what we have learned about the brain? Viewing English language learners through the lens of BB research gives new hope to educators and turns problems into possibilities. BBL does not give us strict directions to follow rather it enables us to consider the structure of our brain at the phase of making decision. Thus, educators can make more effective decisions in relation to the selection of the most appropriate and effective lesson designs as well as teaching strategies to reach much more students thanks to the knowledge of our brains.

\section{Implications}

1- Teachers would benefit from more professional development on the incorporation of $\mathrm{BB}$ instruction to help them overcome the difficulties of planning, time effectiveness and the changes in the classroom environment to maximize delivery of instruction, student achievement and ensure their ultimate success.

2- Learners, through continuous engagement with BBL, would be enabled to make connections between past and new learning, creates new pathways, strengthens existing pathways and increases the possibilities of future learning retrieval.

3- The findings in neuroscience with those in sociology, chemistry, anthropology, environmental studies, psychiatry, psychology, education, and therapy, should be combined to get powerful applications.

4- The reflection through the e-portfolio raises participants' awareness, develop the connection between theoretical aspects and practice and the perception of their own professional identities.

العدد الثامن والثلاثون




\section{Recommendations}

1- The brain research should not be an add-on program for schools, but rather add to teachers' knowledge base fostering better understanding of how the brain learns - or doesn't learn - and why.

2- Curriculum designers should be responsible for staying abreast of current findings because brain research is providing almost daily updates.

3- Teachers should allow students to reflect to filter, delete useless information, link and retain new information prior to learning.

4- Education administration authorities should provide professional training about $\mathrm{BB}$ teaching strategies to EFL teachers to be integrated appropriately into EFL classes.

5- Strategic staff development within schools and staff development workshops, should aim at helping educators use what is known about the brain and how it learns best to obtain the educational objective of improving student learning and student attitude.

6- Colleges should adopt a rigorous core curriculum in pedagogy based on the best research into how students learn.

\section{Suggestions for further research}

1- Using BBL for developing delivery of instruction with pre-service teachers.

2- The administrative impact on teachers' use of BB instruction.

3- The impact of professional development on the understanding and use of BB instruction.

4- The relationship between $\mathrm{BB}$ teaching and learning at the college level.

5- Matching the right, left and mid brain in teaching and learning with BB teaching strategies or instruction for EFL learners.

6- An action research on the $\mathrm{BB}$ teaching strategies used by teachers and perceived by students in EFL classes.

This study may be replicated with a larger and more diverse sample of EFL instructors from different governates in Egypt. 


\section{Using a Brain-Based Learning Program for Optimizing EFL In-Service Teachers' Professional Delivery of Instruction Dalia Ali Maher Abbass}

\section{References}

Anthony, J. (2008). Reflection and electronic portfolios. Washington State University.

Ashikin, H., Ruhizan, M., \& Rohani, S. (2015). E-portfolio model development for the professional practice bachelor of teaching (PISMP) in Malaysia. Procedia-Social and Behavioral Sciences, 174, 1262-1269.

Barbeiro, M. (2003). What are the implications for lesson design using Dewey's mode of inquiry discovery and Sousa's brain-based research? (Doctoral Dissertation). Seton Hall University. Available from ProQuest Dissertations and Theses database. (UMI No. 3190174).

Barrett, H. (2000). Electronic portfolio Development. School of education. University of Alaska Anchorage.

Barrett, H. (2007). Researching electronic portfolios and learner engagement: The REFLECT initiative. Journal of adolescent \& adult literacy, 50(6), 436-449.

Berk, R. (2005). Survey of 12 strategies to measure teaching effectiveness. International journal of teaching and learning in higher education, 17(1), 48-62.

Biffle, C. (2012). Whole brain teachers of America. Retrieved from www.wholebrainteaching.com.

Bonnema, T. (2009). Enhancing Student Learning with Brain-Based Research. Online Submission.

Burgstahler, S. (2012). Equal access: Universal design of instruction. DO-IT, University of Washington.

Burkett, L. (2014). Brain-based learning: A study on how teachers implement strategies in the traditional classroom (Doctoral dissertation). Capella University. Available from ProQuest Dissertations and Theses database. (UMI No. 3632931). 


\section{Using a Brain-Based Learning Program for Optimizing EFL In-Service Teachers' Professional Delivery of Instruction Dalia Ali Maher Abbass}

Caine, R., \& Caine, G. (1990). Understanding a brain-based approach to learning and teaching. Educational leadership, 48(2), 66-70.

Degan, R. (2012). Brain-Based Guided Experience Approach to Teaching Entrepreneurship Students the Practice of Innovation. Working Paper (No. 89).

Denton, V. (2010). A Case Study on the Professional Development of Elementary Teachers Related to Brain Research and the Strategies Used to Help Struggling Readers. (Doctoral Dissertation). Widener University (Available from ProQuest Dissertations and Theses database. (UMI No. 3415926).

Giuseppe Rossi, P., Magnoler, P., \& Giannandrea, L. (2008). From an eportfolio model to e-portfolio practices: some guidelines. CampusWide Information Systems, 25(4), 219-232.

Gozuyesil, E., \& Dikici, A. (2014). The Effect of Brain Based Learning on Academic Achievement: A Meta-Analytical Study. Educational Sciences: Theory and Practice, 14(2), 642648.

Gülpinar, M. (2005). The Principles of Brain-Based Learning and Constructivist Models in Education. Educational Sciences: Theory \& Practice, 5(2), 299-306.

Haghighi, M. (2013). The effect of brain-based learning on Iranian EFL learners' achievement and retention. Procedia-Social and Behavioral Sciences, 70, 508-516.

Harrington, K., \& Luo, T. (2016). E-portfolios: supporting reflection and deep learning in high-impact practices. Peer Review: Association of American Colleges \& Universities, 18(3).

Huang, H. (2006). Brain-based teaching strategies used to teach English as a foreign language (EFL) in Taiwan high schools, colleges, and universities. Spalding University. Available from ProQuest Dissertations and Theses database. (UMI No. 3301346 


\section{Using a Brain-Based Learning Program for Optimizing EFL In-Service Teachers' Professional Delivery of Instruction Dalia Ali Maher Abbass}

Jensen, E. (2011). Brain-based education in action. Educational Horizons, 90(2), 5-6.

Jenson, E. (2009) Brain-Based Lesson Planning Strategies. Retrieved from http://www.brainbasedlearning.net/brain-based-lessonplanning-strategies/

Kagan, S. (2001). Kagan structures are brain-based. Kagan online.

Krummick, J. (2009). Brain Based Research (BBR) learning methods usage and professional development in pre-K through third grade teachers in Florida. (Doctoral Dissertation) Northcentral University, Prescott, Arizona, U.S.A. Available from ProQuest Dissertations and Theses database. (UMI No. 3383116)

Lombardi, J. (2004). Practical ways brain-based research applies to ESL learners. The Internet TESL Journal, X (8), 1-4.

Lombardi, J. (2008). Beyond learning styles: Brain-based research and English language learners. The Clearing House: A Journal of Educational Strategies, Issues and Ideas, 81(5), 219-222.

Parkes, K., Dredger, K., \& Hicks, D. (2013). E-Portfolio as a Measure of Reflective Practice. International Journal of e-Portfolio, 3(2), 99115 .

Quiles- Moukaddem, M. \& Hernandez, T. (2011). Brain-Compatible Teaching Strategies. Education Forum. Workshop paper.

Radin, J. (2005). Brain research and classroom practice: Bridging the gap between theorists and practitioners (Doctoral dissertation). Colorado State University, Fort Collins, Colorado, U.S.A. Available from ProQuest Dissertations and Theses database. (UMI No. 3173083)

Radin, J. (2009). Brain-Compatible Teaching and Learning: Implications for Teacher Education. Educational Horizons, 88(1), 40-50. 


\section{Using a Brain-Based Learning Program for Optimizing EFL In-Service \\ Teachers' Professional Delivery of Instruction Dalia Ali Maher Abbass}

Siercks, A. (2012). Understanding and achieving brain-based instruction in the elementary classroom a qualitative study of strategies used by teachers. (Master's Thesis). University of Central Florida. Orlando, Florida.

Sikes, S. (2009). Applying brain-based teaching techniques to Great Expectations methodology (Doctoral dissertation). Walden University). Available from ProQuest Dissertations and Theses database. (UMI No.3366826).

Valipour, V. \& Araghi, S. (2014). Brain-based learning strategies and its effects on student outcome in university aged Iranian EFL students. Indian Journal of Fundamental and Applied Life Sciences, 4 (2), 230-233

Van Roekel, B. (2002). Brain-based learning: Implications for the elementary classroom. (Master's Theses). Dordt College. Retrieved from http://digitalcollections.dordt.edu/med theses

Van Tartwijk, J., \& Driessen, E. (2009). Portfolios for assessment and learning: AMEE Guide no. 45. Medical teacher, 31(9), 790-801.

Wagner-Heaston, M. (2006). Brain compatible teaching and learning in the foreign language classroom: Teachers' voices. (Doctoral Dissertation). Colorado State University, Fort Collins, Colorado. Available from ProQuest Dissertations and Theses database. (UMI No. 3233380.

Willis, J. (2007). Review of research: Brain-based teaching strategies for improving students' memory, learning, and test-taking success. Childhood Education, 83(5), 310-315.

Wilson, L. (2014). A dozen important brain-based concepts. Retrieved from https://thesecondprinciple.com/teaching-essentials/a-dozenimportant-brain-based-concepts/

Yagcioglu, O. (2014). The advantages of brain- based learning in ELT classes. Procedia-Social and Behavioral Sciences, 152, 258-262.

Yu, T. (2011). E-portfolio, a valuable job search tool for college students. Campus-Wide Information Systems, 29(1), 70-76. 